\title{
A Mega-Tsunami in the Baltic Sea 1171 BC: Geological Records with Special Reference to the Lake Mälaren Area in Sweden
}

\author{
Nils-Axel Mörner 1* , Björn Ambrosiani2 ${ }^{2}$ Phyllis Anderson Ambrosiani ${ }^{2,3}$ \\ ${ }^{1}$ Paleogeophysics \& Geodynamics, Stockholm, Sweden \\ ${ }^{2}$ Swedish National Heritage Board, Stockholm, Sweden \\ ${ }^{3}$ Department of Archaeology and Ancient History, Uppsala University, Uppsala, Sweden \\ Email: phyllis.anderson_ambrosiani@arkeologi.uu.se
}

How to cite this paper: Mörner, N.-A. Ambrosiani, B. and Ambrosiani, P.A. (2020) A Mega-Tsunami in the Baltic Sea 1171 BC: Geological Records with Special Reference to the Lake Mälaren Area in Sweden. International Journal of Geosciences, 11, 667-707. https://doi.org/10.4236/ijg.2020.1110034

Received: September 16, 2020

Accepted: October 27, 2020

Published: October 30, 2020

Copyright $\odot 2020$ by author(s) and Scientific Research Publishing Inc. This work is licensed under the Creative Commons Attribution International License (CC BY 4.0).

http://creativecommons.org/licenses/by/4.0/

(c) (i) Open Access

\begin{abstract}
At about 3000 C14-year BP or 1200 cal. yrs BC, the Baltic Sea experienced a mega-tsunami with a wave-height of $10 \mathrm{~m}$ or more, and a run-up height of up to $16.5 \mathrm{~m}$. This event had significant geological and archaeological effects. We explore the records from the Lake Mälaren area in Sweden. The tsunami event is linked to seismic ground shaking and methane venting tectonics at several sites. The triggering factor is proposed to be the Kaali meteor impact in Estonia of the same age. The documentation of a mega-tsunami in the middle of the Bronze Age has wide implications both in geology and in archaeology. The archaeological key sites at Annelund and Apalle are reinterpreted in terms of tsunami wave actions remodelling stratigraphy. By extensive coring, we are able to trace the tsunami effects in both off-shore and on-shore environment. At the time of the event, sea level was at $+15 \mathrm{~m}$ (due to isostatic uplift). The tsunami wave erosion is traced $13.5 \mathrm{~m}$ below sea level. The tsunami run-up over land is traced to $+29.5 \mathrm{~m}$ to $+31.5 \mathrm{~m}$ (occasionally even higher), implying a run-up of 14.5 - $16.5 \mathrm{~m}$. In Ångermanland, the tsunami event was absolutely dated at 1171 varve years BC. Archaeologically, the tsunami event coincides well with the transition between Periods II and III of the South Scandinavian Bronze Age. Period III has traditionally been difficult to identify in the cultural materials of the Lake Mälaren region.
\end{abstract}

\section{Keywords}

Tsunami Deposits, Mega-Tsunami, Wave Height and Run-Up, Kaali Impact, Archaeological Reinterpretations, The Bronze Age, Lake Mälaren Area, Sweden 


\section{Introduction}

Today, Sweden has a low to moderately low seismic activity. For a long time, this was also considered to be the case for the entire postglacial period of Sweden and Fennoscandia. This idea totally changed in the late $20^{\text {th }}$ century, when it became clear that Sweden was a high-seismic region in deglacial time when the rate of glacial isostasy peaked [1]. Thanks to intensive field work this was later elevated to a new paradigm [2], documenting 52 separate paleoseismic events in the last 12,000 years. Each event was documented by multiple criteria (lending internal support and control to each of the events; [3]. Tsunami events were recorded at an increasing number of sites [2] [3] [4] [5] [6] up to 17 events [7] [8] [9]. The tsunami wave-heights observed provided an independent method of estimating the seismic magnitude of ground shaking [9].

This implies that tsunami events have become a natural process in the postglacial evolution of the Baltic and the Kattegat Seas. Originally, all the events at about 3000 - 4000 BP were believed to represent separate paleoseismic events generating local tsunamis [2]. The first thing pointing to something different was that the events recorded at Hudiksvall and Forsmark could be combined into one single event occurring $2900 \mathrm{C} 14$-yrs BP [8]. Not until recently, did it become obvious that there was one big tsunami event at $3000 \mathrm{BP}$ or $1200 \mathrm{cal}$. yrs $\mathrm{BC}$ (Figure 1), which was Baltic-wide and was initiated by the Kaali impact event [10] [11]. This is where the present paper starts.

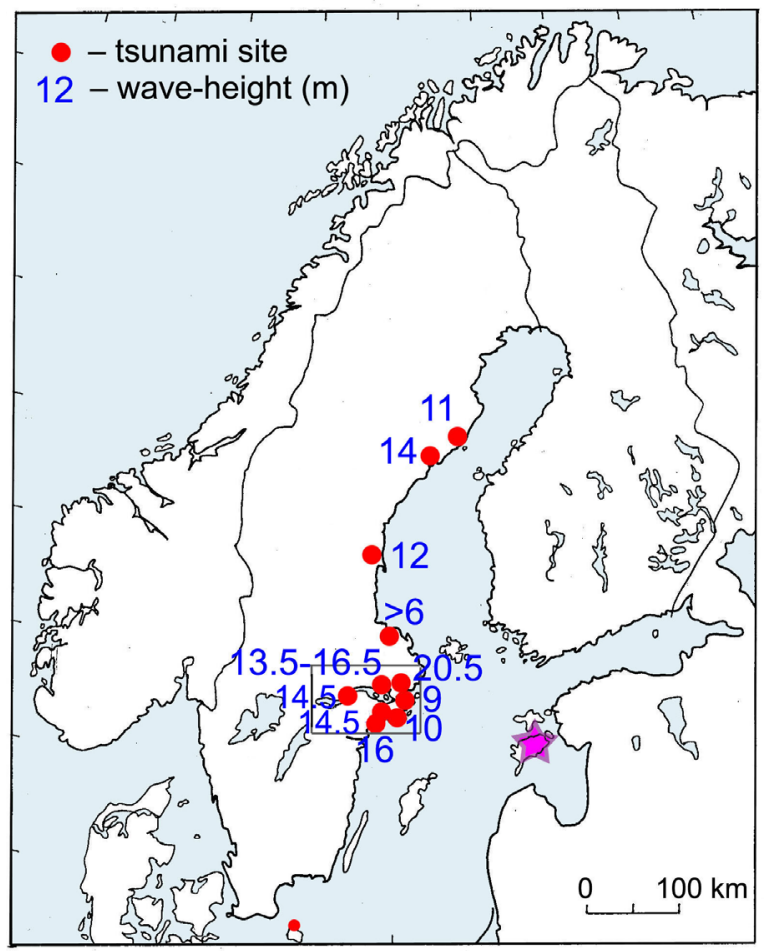

Figure 1. Location of sites where the 3000 BP mega-tsunami has been documented (red dots) and the run-up in metres recorded. Purple star gives location of the Kaali impact crater. 


\subsection{What Is a Tsunami?}

Earthquakes, impacts, submarine slides, submarine volcanic eruptions and submarine explosions are all factors that can set up tsunamis [9] [12], which are characterized by their high wave diameter (hundreds of meters to a couple of kilometres) and their rapid horizontal travel-time (in the order of several 100 $\mathrm{km} / \mathrm{h}$ ). Usually, the tsunami is composed of several separate waves (termed a tsunami train).

When the tsunami wave breaks in over land it usually causes extensive erosion, destruction and relocation of material. The damage often takes directly disastrous dimensions (at the March 11, 2011, tsunami in Japan, 18,000 persons were killed, nuclear power plants were seriously damaged and 452,000 persons had to be relocated; at the December 26, 2004, tsunami in Indonesia, 230,000 persons were killed; at the November 1, 1755, Lisbon earthquake and tsunami, at least 60,000 persons were killed and damage became known as "the destruction of Lisbon"; just to name a few examples).

At the same time, a tsunami event may run-up and draw-back leaving hardly any traces. Even in seriously damaged coastal segments, it may after only a few years be very hard to retrieve the tsunami records. Therefore, the recording of past tsunami events takes a lot of time and effort to document.

When the base of the rotating tsunami waves hit the seabed surface, it may generate erosion (as illustrated in Figure 6 of [7]; and recorded by the "submarine sandstorm" of [13]). When the tsunami wave rises to a high wall and breaks in over the coast, the shore-morphology may become deformed and modified (e.g. [14]). The tsunami wave runs up over land incorporating loose objects and eroded material, which then becomes deposited as a tsunami bed (termed: $t s u$ namite) in lake basins and depressions. These tsunami beds have a graded bedding (fining upwards) and usually include marine planktonic microfossils [7]. Similar deposits are formed by the back-swash wave.

It is these type characteristics, we are tracing in the field when we are trying to record, document and date a tsunami event.

\subsection{Working in the Absence of References}

Before 1996 [4] [5], no one knew that tsunami events had occurred in Sweden. Therefore, both geologists and archaeologists were unable to present such an interpretation, and had to propose other explanations. This is not strange, just a matter of scientific advancement.

New ideas and observational facts are natural parts of scientific development; and growing knowledge. When we are facing necessary revisions of older material, the quality of previous documentation plays a vital role. The archaeological material by Fagerlund and Hamilton [15] and Ullén [16], which we are revising below, both meet this high-quality criterion. The geological map descriptions are less useful, but includes reports of strange records of clay above gyttja clay [17] [18] [19] [20], which can now be understood in terms of off-shore 
re-working by the mega-tsunami here described (below).

Inevitably, the new concept of a mega-tsunami at about $3000 \mathrm{BP}$ will lead to cases of revision both in geology and archaeology.

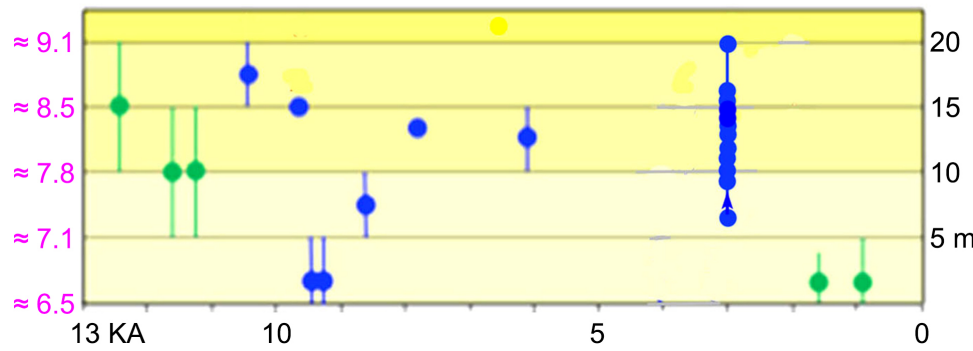

Figure 2. The Swedish paleoseismic database now includes 13 tsunami events; 5 in the Kattegatt Sea (green) and 8 in the Baltic (blue) plotted chronologically with respect to observed wave heights. Purple figures to the left give corresponding earthquake magnitudes as read from the magnitude/wave-height relationship in Mörner [9]. The mega-tsunami at $3000 \mathrm{BP}$ is documented at fifteen sites in Sweden (Figure 1).

\section{Material and Methods}

Tsunami events with a date of about $3000 \mathrm{BP}$ or $1200 \mathrm{cal}$. yrs BC, have been reported from Umeå [2] [21], Hudiksvall [2] [8] [22], Forsmark [7] [8] [23], Upplands Väsby [24], Enköping (this paper; [10] [11], Eskilstuna (this paper), Saltsjöbaden [11], Åker (this paper, [2] [3] [25]), Södertörn [11] [22] [26], and Tystberga [11] [22] as shown in Figure 1.

The observed tsunami wave-height (or run-up) is in the order of $10-16 \mathrm{~m}$ ( $>6$ to $20.5 \mathrm{~m}$ ), which corresponds to a seismic ground shaking of magnitude ranging from M 7.8 to 8.6. The Swedish data set is given in Figure 2 on the basis of observed relation between tsunami wave height and earthquake magnitude [9] (here redrawn with one Baltic-wide event at around $3000 \mathrm{BP}$ ).

The methods applied are sediment coring, sediment characteristics, radiocarbon dating (the AMS technique) and analysis of relevant literature.

Sediment coring was performed at 24 sites (totalling 52 cores): with the majority of 24 sites (A-Y) in the Enköping-Bålsta area. The sediment characteristic is a prime factor for the identification of tsunami events (e.g. [27]). In this case, it was important to observe, document and interpret both the on-land signals and the off-shore signals. The core taken above the $+15 \mathrm{~m}$ shore level at $3000 \mathrm{BP}$ usually contained tsunamites starting with a distinct erosional surface to the clay below (sharp and irregular). Often erosion could have gone down into the varved clay from the deglaciation time, implying that 7000 - 8000 years of sediment was removed. The tsunamite itself consists of a sandy layer of graded bedding (fining upwards) or unsorted beds with grains lacking rounding. The highest altitude of their occurrence provides a measure of the tsunami wave-height and run-up capacity (Figure 1). The tsunamite found in the off-shore environment below $+15 \mathrm{~m}$ had a quite different appearance. Usually, it was a bed of pure fine clay from the settling of material set in suspension by the base of the tsuna- 
mi wave hitting the seabed and generating erosion. This was understood by the occurrence of lagoonal gyttja-clay below the fine clay. This surprising stratigraphy was observed by [17] [18] [19] [20], but not understood. The tsunamite characteristics are illustrated in Figure 3 and were used as a key to the understanding of the stratigraphy observed in the sediments cores collected (cf. Figure 5).

\begin{tabular}{|c|c|c|}
\hline$+15-28.5(29$ & 5) $\mathrm{m}$ & $+10- \pm 0 \mathrm{~m}$ \\
\hline post-tsunaami & lake or bog or land deposits & post-tsunami \\
\hline & $\begin{array}{lr}\text { tsunamite } & \text { fine clay } \\
\text { graded bedding } & \text { from settling } \\
\text { unsorted, angular grains } & \text { suspended particles }\end{array}$ & \\
\hline $\begin{array}{l}\text { pre-tsunami } \\
\text { deposits }\end{array}$ & $\begin{array}{l}\stackrel{\begin{array}{r}\text { sometimes erosion } \\
\text { grosion surface }\end{array}}{\text { gytja-clay }} \\
\text { glacial clay to Littorina clay }\end{array}$ & $\begin{array}{c}\text { pre-tsunami } \\
\text { deposits }\end{array}$ \\
\hline
\end{tabular}

Figure 3. Characteristics of tsunami beds (tsunamites) in the on-shore area (left) and off-shore area (right) with respect to the $+15 \mathrm{~m}$ sea level at the time of the tsunami event.

\section{The Lake Mälaren Valley}

Lake Mälaren Valley (Swed: Mälardalen) is a broad lowland valley stretching 200 $\mathrm{km}$ inland from Stockolm and including both Lake Mälaren and Lake Hjälmaren. The location of the sites (3.1 to 3.10) here discussed are given in Figure 4.

Our collaboration on the wider documentation of the 3000 BP tsunami in geological and archaeological data started with the Tolan-project in Upplands-Väsby [24]. The first target was the archaeological investigation at Annelund at Enköping (15), because at this site a "silt-layer" of unknown origin had caused much confusion. It seemed natural to suspect that the "silt-layer" at Annelund might be a tsunami layer. This idea initiated an extensive coring campaign (Figure 5).

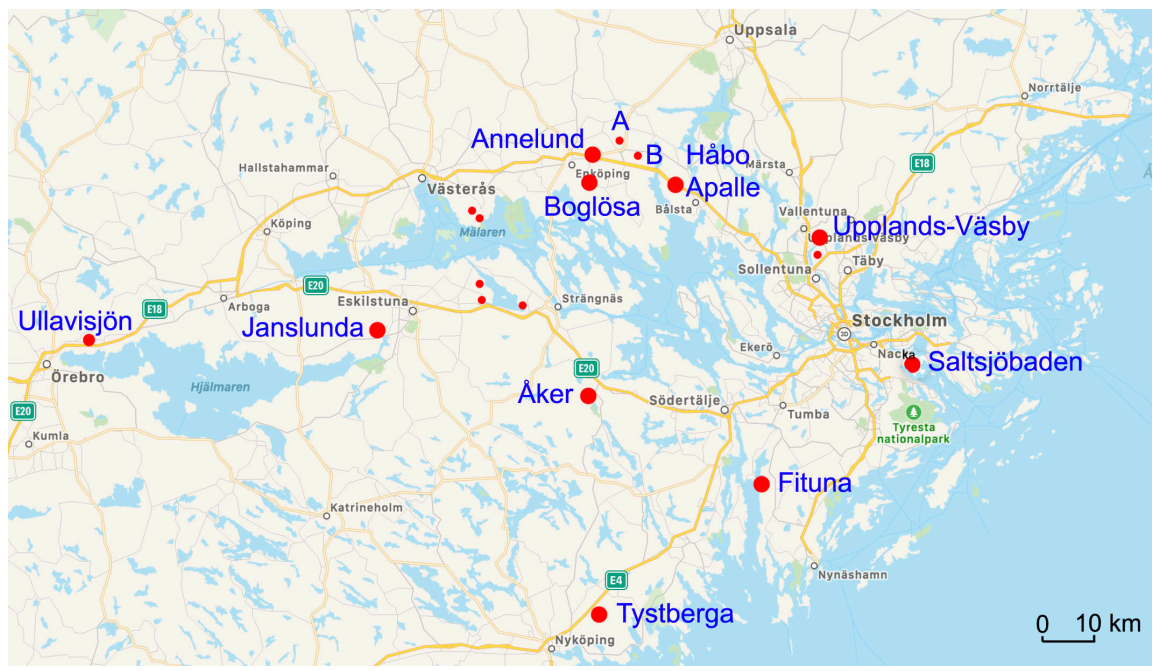

Figure 4. The Lake Mälaren Valley and location of sites discussed (red dots and blue text). 


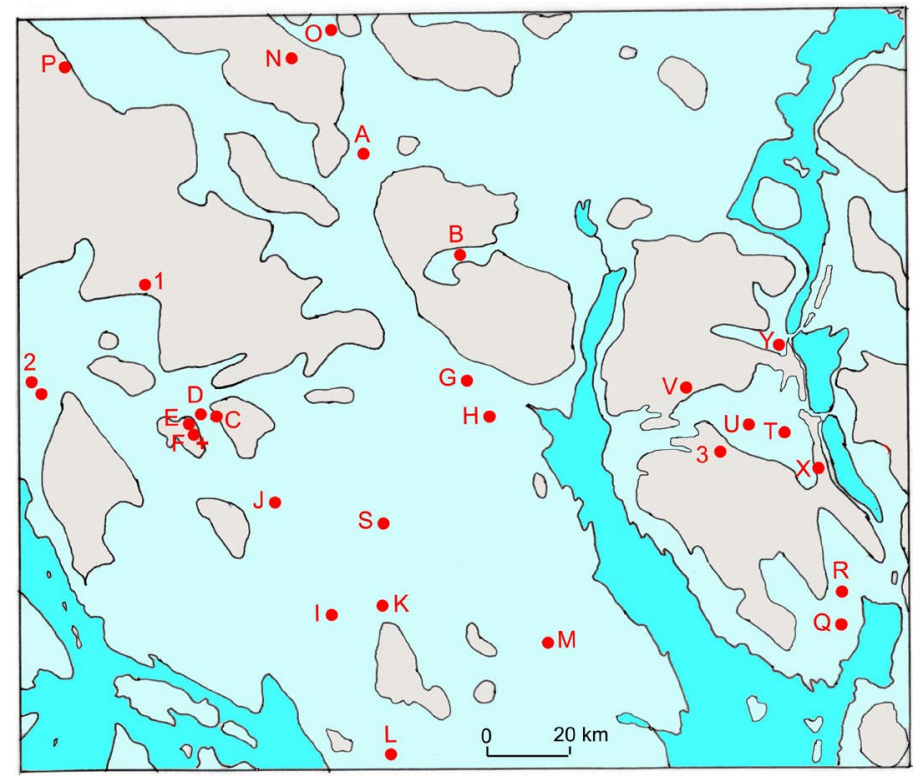

Figure 5. The Enköping-Bålsta area with coring sites (A-Y) and archaeological sites (1 3) discussed. Grey areas refer to ground above $+25 \mathrm{~m}$ (Lake Mälaren: blue).

The first sites chosen for sediment coring were Sites A and B (Figure 4, Figure 5): the bogs Skillinge Mosse at $+16 \mathrm{~m}$ (A) and Sävsta Kärr at $+18 \mathrm{~m}$ (B).

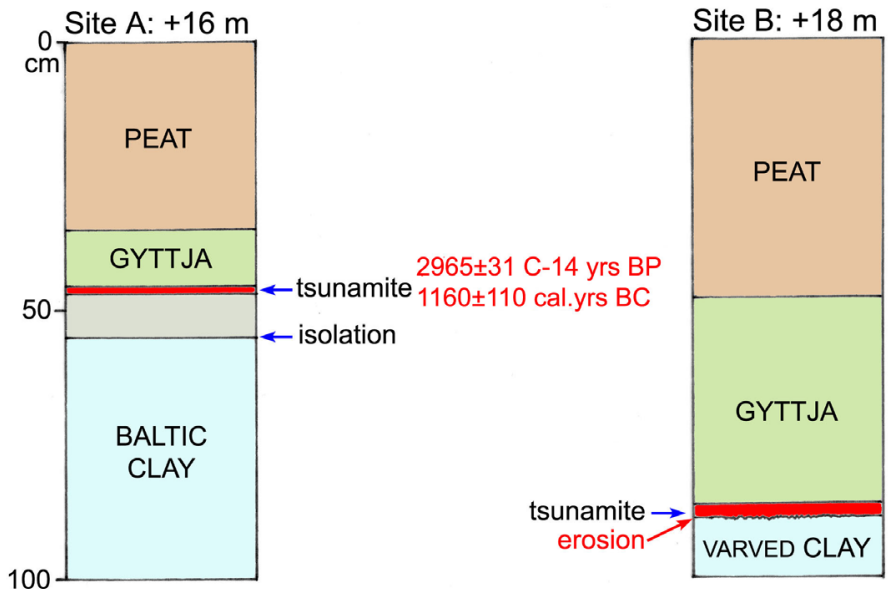

Figure 6. Stratigraphy obtained in the cores at Sites A (Skillinge Mosse) and B (Sävsta Kärr).

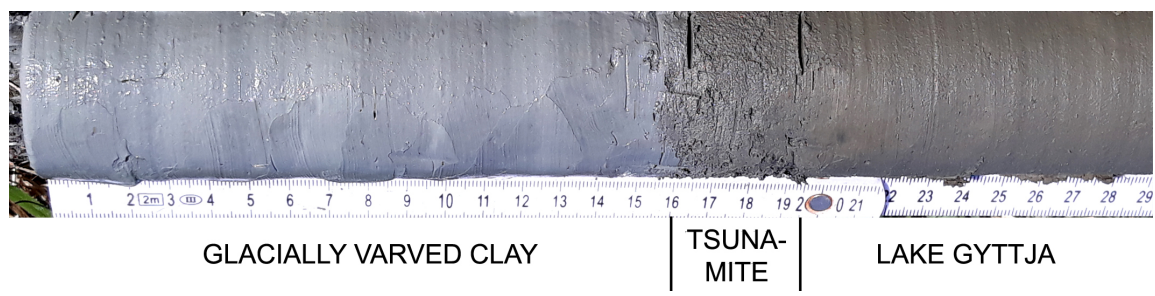

Figure 7. Sediment core at Site B recording the tsunamite at 16.0 - 19.4 and the irregular erosion surface at about $16 \mathrm{~cm}$ into the glacial varved clay, implying a hiatus of about 7000 years. 
Skillinge Mosse (coring site A) is a bog at an elevation of $+16 \mathrm{~m}$ (Figure 6). It lies in a wide depression with an original outlet threshold of about $+21 \mathrm{~m}$. At a depth of about $45 \mathrm{~cm}$, there is a $1.2 \mathrm{~cm}$ layer of clay gyttja bounded by faint erosion surfaces. This was interpreted as a potential tsunami layer. It was radiocarbon dated at $2965 \pm 31 \mathrm{C} 14$-yrs BP or $1173 \pm 52(68.25 \%)$ and $1160 \pm 110$ (94.4\%) cal. yrs BC. Below is a $9.3 \mathrm{~cm}$ layer of gyttja-clay representing a lagoonal lake phase. This is consistent with a sea level regression passing the outlet threshold and isolation a lagoonal lake. Shortly after, a spike event occurred (i.e. the tsunami) and rose sea level well above the threshold depositing the $1.2 \mathrm{~cm}$ tsunami layer dated.

Sävsta Kärr (coring site B) refers to a swamp and bog at an elevation of $+18 \mathrm{~m}$ (Figure 6). It occupies a depression (Figure 5) with an outlet threshold at about $+20 \mathrm{~m}$. Coring was performed at two nearby sites. A quite typical tsunamite was retrieved between lacustrine gyttja and Baltic clay. The tsunamite is $2.8 \mathrm{~cm}$ thick and consists of a clayey silty sand with a strong erosional contact to the clay below, which is a varved clay from the deglaciation period, implying that about 7000 years' Baltic sediments were removed by the erosion of the tsunami event (Figure 7).

From these two sites we got stratigraphic evidence of a tsunami (Figure 6) and a high quality C14 date of $2965 \pm 31$ C14-yrs BP or $1160 \pm 110(1173 \pm 52)$ cal. yrs BP. This means full agreement with previous records [7] [8] [10] [11] [24] and time coincidence with the Kaali impact in Estonia [10] [11]. It also worked as the incitement of the Enköping-Bålsta investigation here presented.

\subsection{The Annelund Archaeological Site at Enköping}

In the eastern part of the city of Enköping, an archaeological site (Figure 3, site 1 in Figure 4) was discovered in connection with the construction of a new highway at Annelund, and documented [15]. Above archaeological material from the Early Bronze Age and partly also above a gallery grave from the Late Neolithic, but below archaeological material from the Late Bronze Age and the Iron Age, there is a layer termed the "silt layer" [15]. It has a wide lateral extension (Figure 8). It is $5-30 \mathrm{~cm}$ thick and reaches up to about $28.5 \mathrm{~m}$. Occasionally, it contains lenses of gravel and stones of 5 to $20 \mathrm{~cm}$ size. It exhibits flow structures and includes Baltic diatoms. Obviously, it is a Baltic Sea deposit accumulated under quite strong water flow forces. Its origin remained unsolved, however, which posed major interpretational problems for the stratigraphy and chronology [15].

We now propose that the so-called "silt layer" (red in Figure 8) constitutes a sedimentary bed laid down during a tsunami event. If so, it is a "tsunamite" [27]. This event must have occurred at about $3000 \mathrm{BP}$, as suggested by C14-dates (Ua-1631, Ua-1632) giving $2950 \pm 90$ and $3080 \pm 120 \mathrm{BP}$ or $1192 \pm 177 \mathrm{cal}$. yrs BC and $1308 \pm 188$ cal. yrs BC.

The fact that the "silt layer" contains lenses of gravel and stones ranging from 5 to $20 \mathrm{~cm}$ is consistent with a rapid and violent mode of deposition. 


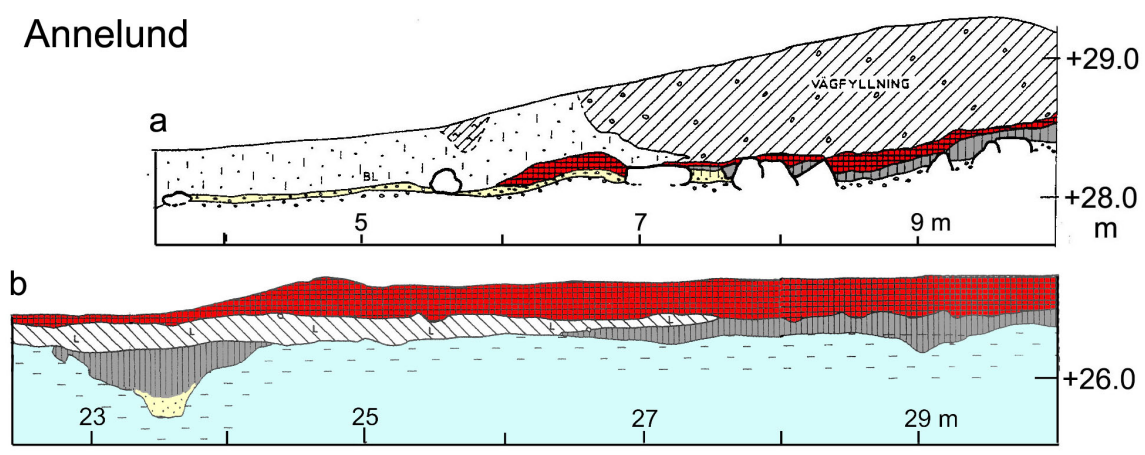

Figure 8. Two profiles from the archaeological site Annelund: "silt-layer" red, cultural layer dark, sand yellow and clay blue. The silt-layer reaches up to $+28.5 \mathrm{~m}$ in (a), is quite extensive in (b), and rests upon cultural layers from the late Neolithic and early Bronze Age (redrawn from [15].

At about 3000 BP sea level was at about $+15.0 \mathrm{~m}$. As the "silt bed" reaches up to about $+28.5 \mathrm{~m}$ in Annelund, the tsunami wave-height plus tsunami run-up must have been at least $13.5 \mathrm{~m}$ as illustrated in the local sea level curve (Figure 9).

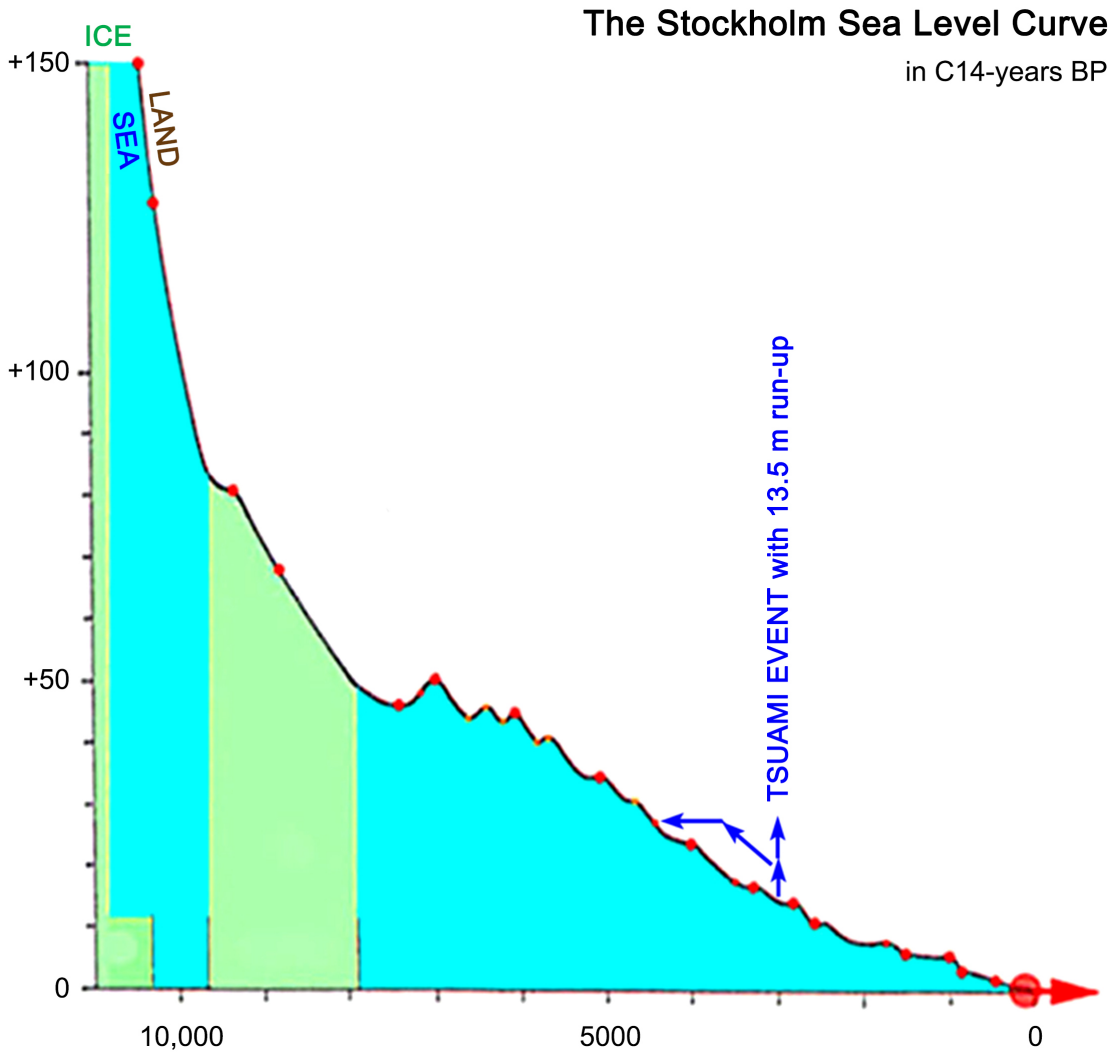

Figure 9. Sea level changes observed. At about 3000 BP, sea level was at $+15 \mathrm{~m}$, and the area was struck by a mega-tsunami with w run-up of 13.5 to $16.5 \mathrm{~m}$ in the Enköping-Bålsta area.

By an intensive coring program (52 sediment cores at 24 sites, Figure 5), the tsunami event was well documented by the occurrence of "tsunamites" ranging 
in elevation from $+1.6 \mathrm{~m}$ to $+29.5 \mathrm{~m}$, covering quite a wide area (Figure 5).

Close to Annelund, there is a bog, Fanna Mosse, (Figure 5, site 2) from where there is a pollen-diagram and radiocarbon dates (p. 188 in [15], p. 325 in [28]). The elevation is around $+23 \mathrm{~m}$. The isolation level is dated $3830 \pm 250 \mathrm{C} 14$-years BP, which fits our sea level curve very well (Figure 9). There is no tsunamite recorded. At a depth of only $7.5 \mathrm{~cm}$, there is a decrease in light demanding tree and spruce pollen and an increase in grass pollen, indicative of a short change in environmental conditions. This level is dated at $3060 \pm 100 \mathrm{C} 14$-years BP, which makes a correlation with the tsunami event possible.

The Annelund archaeological site [15] deserves a deeper analysis in view of our suggestion that the "silt layer", in fact, is a tsunami layer deposited at a Baltic-wide tsunami event occurring at about 3000 BP.

The silt layer overlies the Neolithic cultural layer including a gallery grave of Late Neolithic age and a "bone-pit" (A6) at $+27.0-29.1 \mathrm{~m}$. The silt layer extends at about $+26-27 \mathrm{~m}$, and occasionally goes up to $28.0-28.5 \mathrm{~m}$. The silt layer is said to become sandier to the east.

The gallery grave is at its edge covered by a relatively thick layer of littoral sand and gravel (according to [15]). Its level is about $+28.5 \mathrm{~m}$. Because the underlying gallery grave represents land conditions in Late Neolithic time, the littoral sand must represent an extreme storm episode or, in our view, a tsunami event. In the gallery grave, there is a gravel filling (including some bones) above the original land-surface at $+28.5 \mathrm{~m}$.

The littoral sand and gravel separates the gallery grave from a covering mound of brittle burned stones (A1). On the whole there are four, maybe five, mounds of brittle-burned stones. There are also three house-foundations marked by postholes.

Besides the identification of the silt-layer as a tsunamite, the Annelund stratigraphy calls for an additional archaeological revision beyond the scope of this paper.

There are a large number of irregular pits scattered over the investigation area. They are hard to explain and do not seem to fit any known function. Therefore, it has been suggested that they may represent the remains from root systems of removed trees. This is very interesting in view of the tsunami event proposed. An instantaneous flooding of the ground during a tsunami, may have left standing dead trees on the ground, which the people removed, hence creating the irregular pits scattered all over the area (in Fanna Mosse, there are palynological evidence [15] [28] that light demanding trees and spruce decreased just at this time, and grass increased; cf. above).

Unfortunately, we have no C14-dates from the littoral sand and gravel layer covering the gallery grave or from the gravel filling in the gallery grave, which contained skeleton remains from a few persons. Stratigraphy and sediment characteristics clearly show that the area was over-washed by a tsunami in the mid Bronze Age, however. 


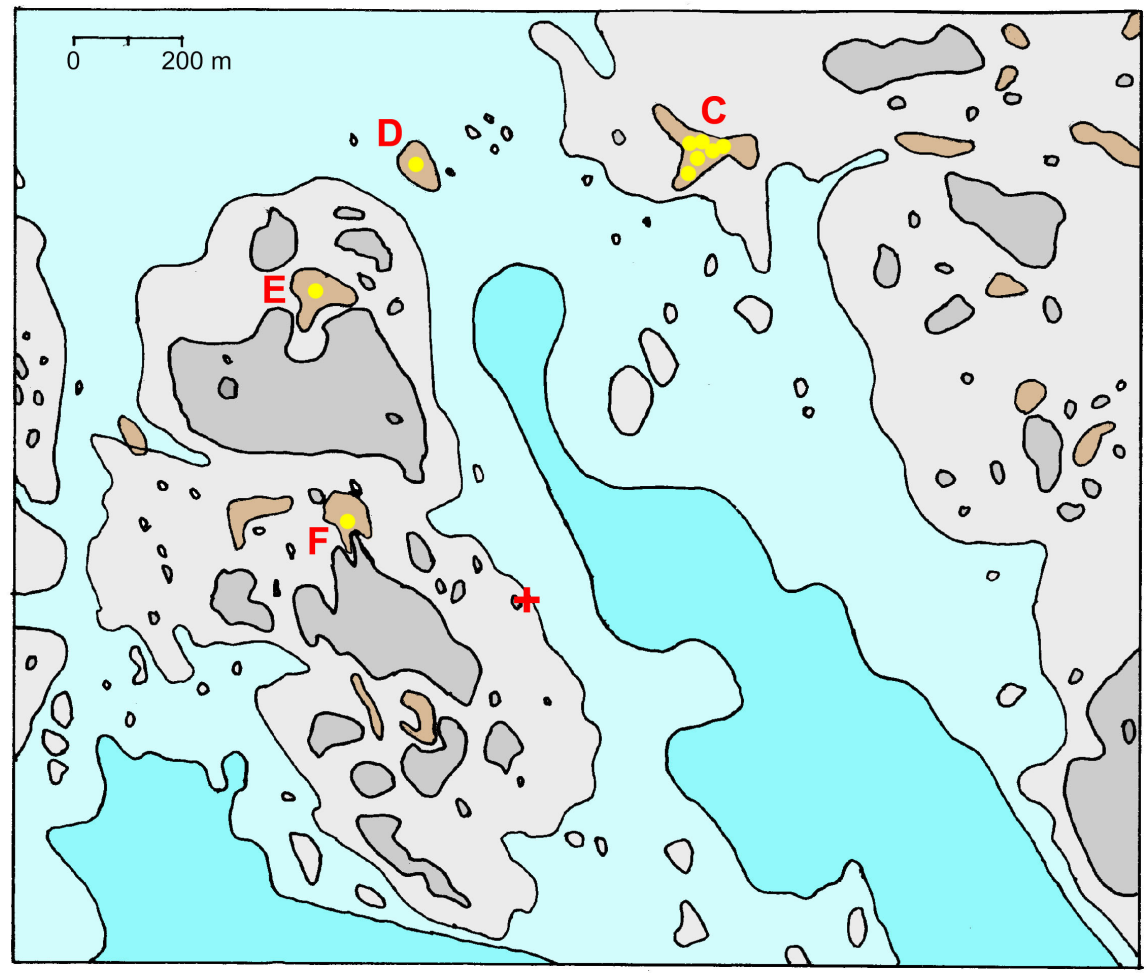

Figure 10. The Boglösa area with coring sites $\mathrm{C}$ at $+25.5 \mathrm{~m}, \mathrm{D}$ at $+24.0 \mathrm{~m}, \mathrm{E}$ at $+29.0 \mathrm{~m}$ and $\mathrm{F}$ at $+29.5 \mathrm{~m}$, and contour lines of $+20 \mathrm{~m}$ and $+25 \mathrm{~m}+30 \mathrm{~m}$. The red + sign refers to the $4.2 \mathrm{~m}$ long rock carving of a ship known as Brandskogsskeppet (see Figure 12).

\subsection{The Boglösa Area}

The Boglösa area lies $5 \mathrm{~km}$ to the south of Annelund (Figure 4). In a small bog situated at $+25.5 \mathrm{~m}$ our third coring was performed (Site $\mathrm{C}$ ) and a very clear tsunami layer was retrieved: a $3.2 \mathrm{~cm}$ layer of sand and gravel with fine sand in the uppermost $0.5 \mathrm{~cm}$ (i.e. a graded bedding as shown in Figure 3 left) between Baltic clay and lacustrine gyttja (only $6.5 \mathrm{~cm}$ thick) and peat. The contact to the clay was strongly erosive and irregular, and cut down into the glacially varved clay (implying the removal of 7000 - 8000 years of sediment). The grains were angular and badly sorted precluding a littoral shore formation.

This very clear tsunami record initiated extended work: with a total of six coring points in Site C, and additional Sites D, E and F (Figure 10).

The tsunami is recorded in all six cores in Site C. It starts with an irregular erosion surface reaching down into the glacially varved clay (implying an extensive hiatus). The tsunami layer is of different character and thickness in the six cores:

$\mathrm{C} 1: 3.2 \mathrm{~cm}$ sand and gravel to fine sand in graded bedding.

C2: erosional hiatus.

C3: $2.3 \mathrm{~cm}$ gravel followed by $18.2 \mathrm{~cm}$ of alternating organic and silty layers.

C4: $5.5 \mathrm{~cm}$ gravelly sand.

C5: $5.7 \mathrm{~cm}$ gravelly sand.

C6: and $1.7-3.2 \mathrm{~cm}$ of silty sandy gravel as shown in Figure 11 . 


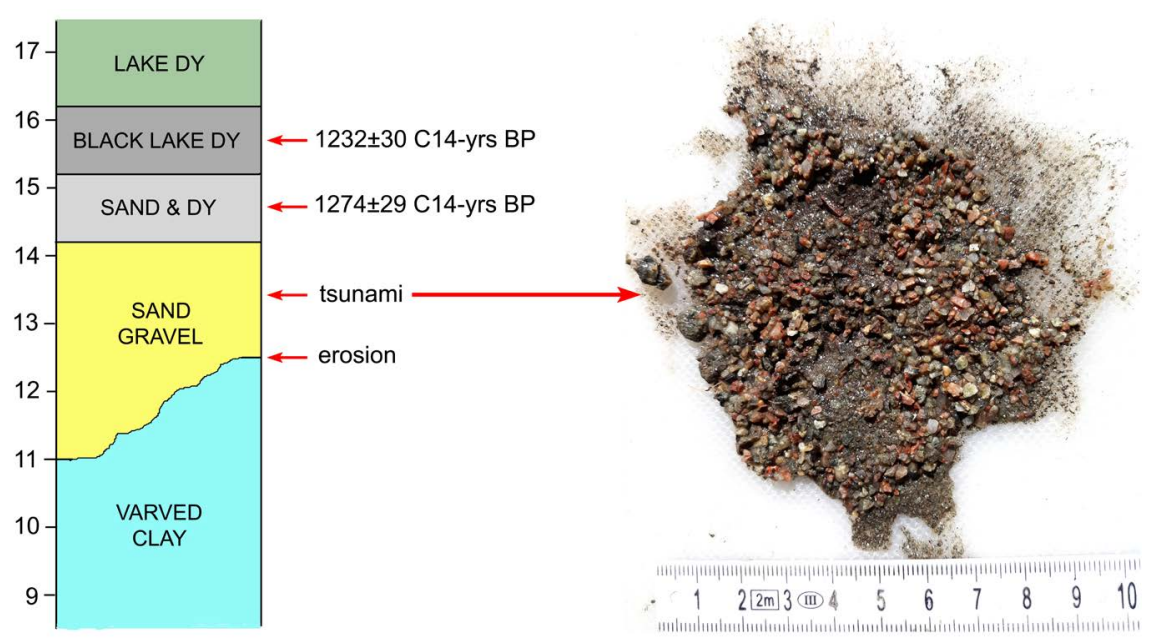

Figure 11. Detailed stratigraphy of the tsunami layer in Core C-6 (in $\mathrm{cm}$ from the base at a depth of $1.0 \mathrm{~m}$ ). Erosion cut irregularly down into the glacially varved clay (i.e. a hiatus of about 7000 years). The tsunamite exhibits graded bedding. It is unsorted (though graded) and the grains are angular (lacking signs of rounding), precluding a littoral shore deposition. The C14-dates show contamination by younger humic acids (the dy material).

Core D at $+24.0 \mathrm{~m}$ showed a strongly weathered clay surface (i.e. land surface) covered by a thin layer of brushwood peat. Core $\mathrm{E}$ at $+29.0 \mathrm{~m}$ had a strong erosional contact at the top of a hard clay. Core $\mathrm{F}$ at $+29.5 \mathrm{~m}$ (two core sites) shows a basal clay with a strong erosional surface at its top, $2.8 \mathrm{~cm}$ of sandy gravel with angular stones (the tsunami bed), $27.0 \mathrm{~cm}$ of lake gyttja, and $34.0 \mathrm{~cm}$ of peat. The Core F stratigraphy indicates that the tsunami wave reached up to, at least, $29.5 \mathrm{~m}$ (i.e. $1.0 \mathrm{~m}$ higher than the silt-layer in Annelund). Two C14-dates were performed: black wood just in top of the tsunami layer gave $335 \pm 29 \mathrm{BP}(1560 \pm$ $90 \mathrm{AD})$ and $1.2 \mathrm{~cm}$ clay gyttja directly above gave $1343 \pm 30 \mathrm{BP}(667 \pm 17 \mathrm{AD})$, indicating far too young ages (and in reversed stratigraphic order) due to roots and humic acids.

In the Boglösa area, there is a famous and quite unique rock carving from the Bronze Age [29] [30], known as "Brandskogsskeppet". The ship is $4.2 \mathrm{~m}$ long. Judging from the size of the men (0.7 - $0.8 \mathrm{~m}$ above their waistlines) and their paddles (about $1 \mathrm{~m}$ long), the ship is likely to be drawn more or less in natural size (Figure 12).

The elevation of the rock carving was leveled at "between 28 and $29 \mathrm{~m}$ above sea level" [29] (or about $+28.5-29.5 \mathrm{~m}$ in the present reference system; p. 31). Consequently, it matched the run-up level of the tsunami wave ( $+28.5 \mathrm{~m}$ in Annelund and $+29.5 \mathrm{~m}$ in Boglösa) perfectly well. This may be a coincidence (BA \& PAA) or a causal linkage to the tsunami event (view here proposed by NAM). In the second case, the place may mark the place of wreckage and death, or the place of a remarkable salvage of ship and men. From a tsunami dynamic point of view, wreckage is likely and salvage possible.

If the men were out fishing in the open water to the south when the tsunami hit the area, the ship may just have been lifted up (as was the case in the Mal- 
dives at the 2004 tsunami; [7]) and moved ashore at the limit of the run-up of the tsunami wave at the hill slope just at or close to where the carving was cut (Figure 13). Consequently, the carving may illustrate a miraculous rescue from the tsunami disaster.

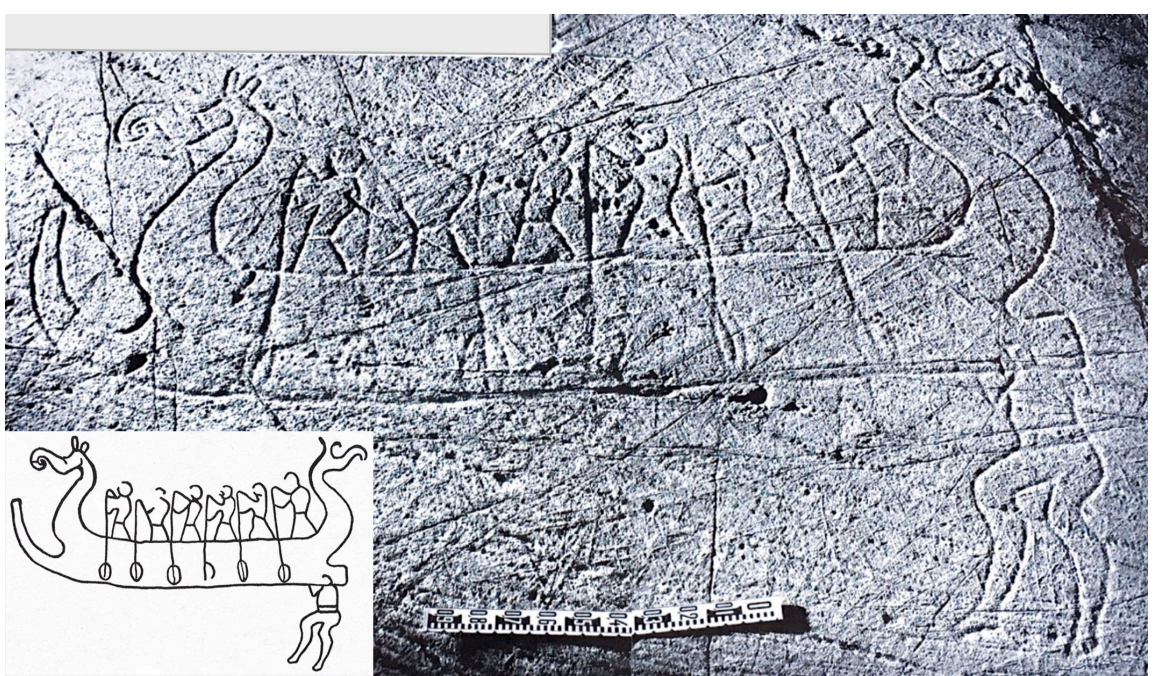

Figure 12. Brandskogsskeppet, a $4.2 \mathrm{~m}$ long rock carving from the Bronze Age (based on [30]). The carving was leveled by [29] at between $+28.0-29.0 \mathrm{~m}$, which implies that the elevation corresponds to the tsunam run-up level. This may be a coincidence or rather a reason to seek a causal connection.

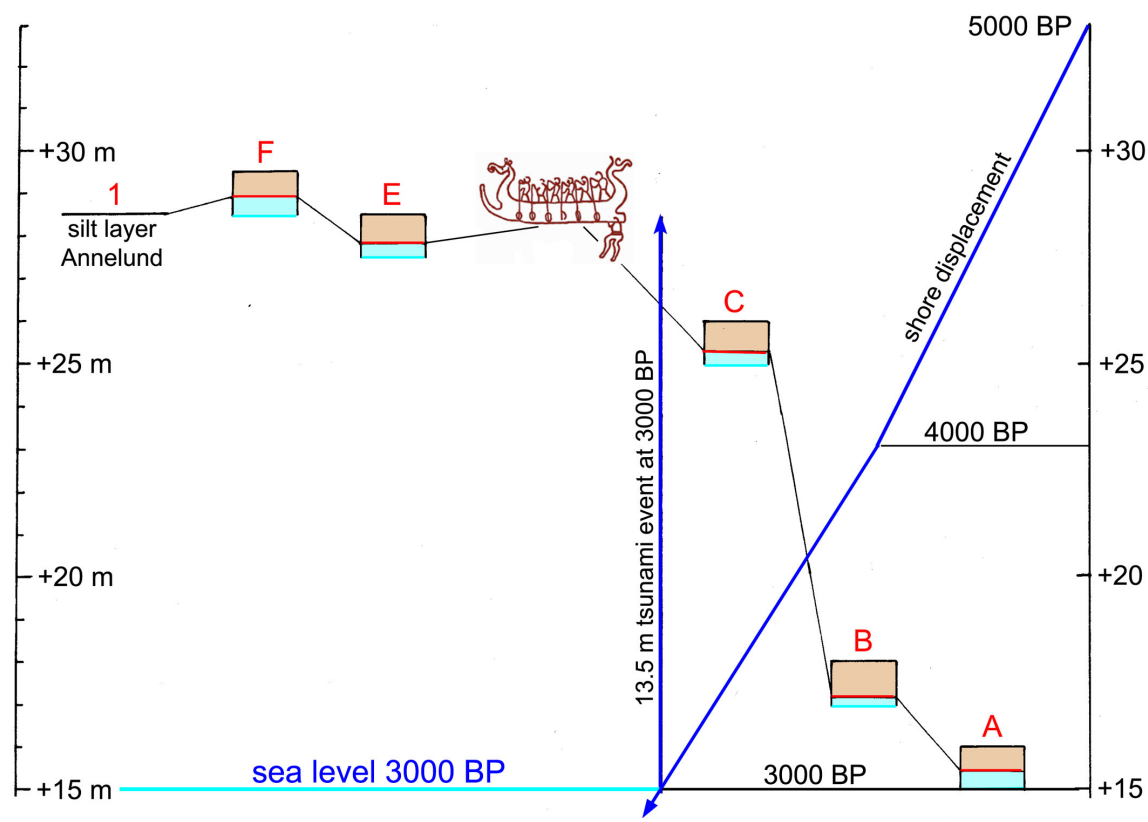

Figure 13. Synthesis of the Enköping tsunami data. Due to the glacial isostatic uplift the shore is continually displaced downwards. When sea is at about $+15 \mathrm{~m}$ at about $3000 \mathrm{BP}$, the mega-tsunami strikes the area, and the tsunami wave instantaneously floods the area up to about $+28.5-29.0 \mathrm{~m}$. The Brandskogsskeppet rock carving lies right at the tsunami run-up level and may commemorate a wreckage or rather the miraculous salvage of ship and men (provided they were out on the open water to the south, from where they may have been "lifted" ashore). 
Figure 13 gives a summary of the tsunami records obtained from Sites A to F, Annelund and the "Brandskogsskeppet" rock carving. The shore was successively displaced downwards due to the glacial isostatic uplift of the area. At about 3000 $\mathrm{BP}$, sea was at $+15 \mathrm{~m}$. At that moment, the region was struck by a mega-tsunami with a wave-height plus run-up height of about $13.5 \mathrm{~m}$ (Figure 9).

In the off-shore environment south and southeast of Boglösa eight sediment cores were taken (Figure 5; G-M, S). Core J at $+14.5 \mathrm{~m}$ shows a $15.0 \mathrm{~cm}$ tsunamite of silt with angular stones between $48 \mathrm{~cm}$ of weathered fine clay above and $>30 \mathrm{~cm}$ of weathered glacial clay below. This means that it has a characteristic of an on-shore to shore tsunamite (Figure 3 ). The other cores have typical off-shore tsunami characteristics (Figure 14), where the tsunami is represented by a layer of fine clay from the settling of particles set in suspension by the erosion of the clayey seabed surface (Figure 3, right side). It implies that the erosion by the base of the passing tsunami wave has gone down, at least to $+0.5 \mathrm{~m}(\mathrm{H})$ to $+1.5 \mathrm{~m}(\mathrm{G})$, i.e. $14.5 \mathrm{~m}$ to $13.5 \mathrm{~m}$ below the sea level at $+15 \mathrm{~m}$. This is as much below sea level (Figure 14) as was recorded above sea level (Figure 12), which fits well with the theoretical symmetry of a tsunami wave (cf. 5.1, below).

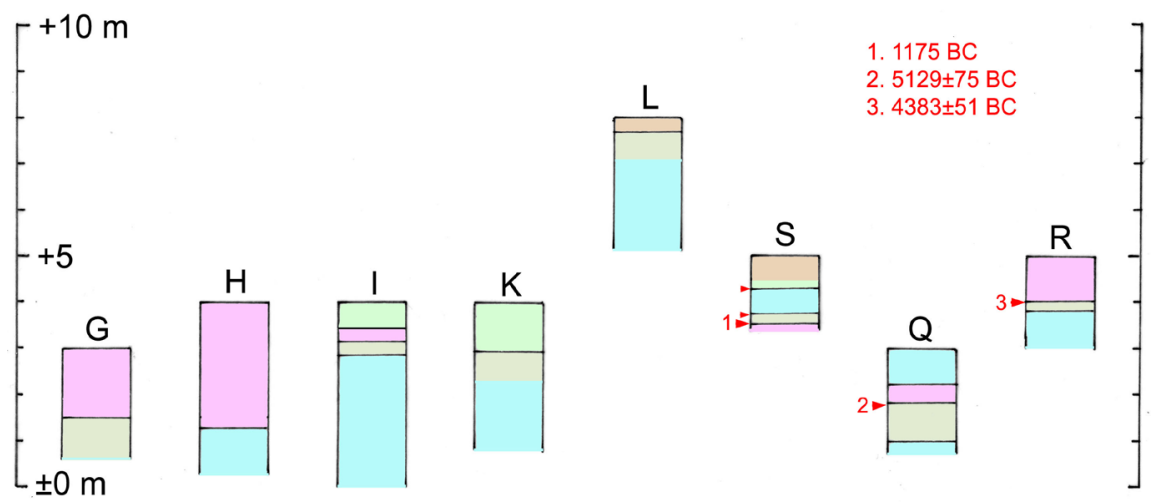

Figure 14. Tsunami records from the off-shore environment, indicating basal wave trimming of the seabed at least down to +0.5 to $+1.5 \mathrm{~m}$, i.e. 14.5 to $13.5 \mathrm{~m}$ below sea level, and generating a submarine "cloud" of suspended matter, deposited as a fine clay (violet) on top of shallow-water gyttja-clay (greenish grey).

The off-shore characteristics of a tsunami event in the form of erosion of the seabed (Figure 3, right hand image) fit the model of [7] quite well.

In the local map descriptions [17] [18] [19] [20], it had been observed that there occasionally occurred fine clay on top of gyttja clay. They noted it as "unusual" and were not able to present any tenable interpretation. They undertook a number of grain-size analyses, however, which are quite informative. The covering fine clay consists of $>50 \%$ clay, $<50 \%$ silt and organic matter $<2 \%$, i.e. a composition fitting the deposition of suspended matter. The gyttja clay below consists of $4 \%-5 \%$ sand (even course sand particles), $<50 \%$ silt, $<50 \%$ clay and with organic matter $>2 \%$ (up to $4 \%-5 \%$ ), implying a combination of bed-load transport and suspended matter flocculation (in agreement with our coring data). 


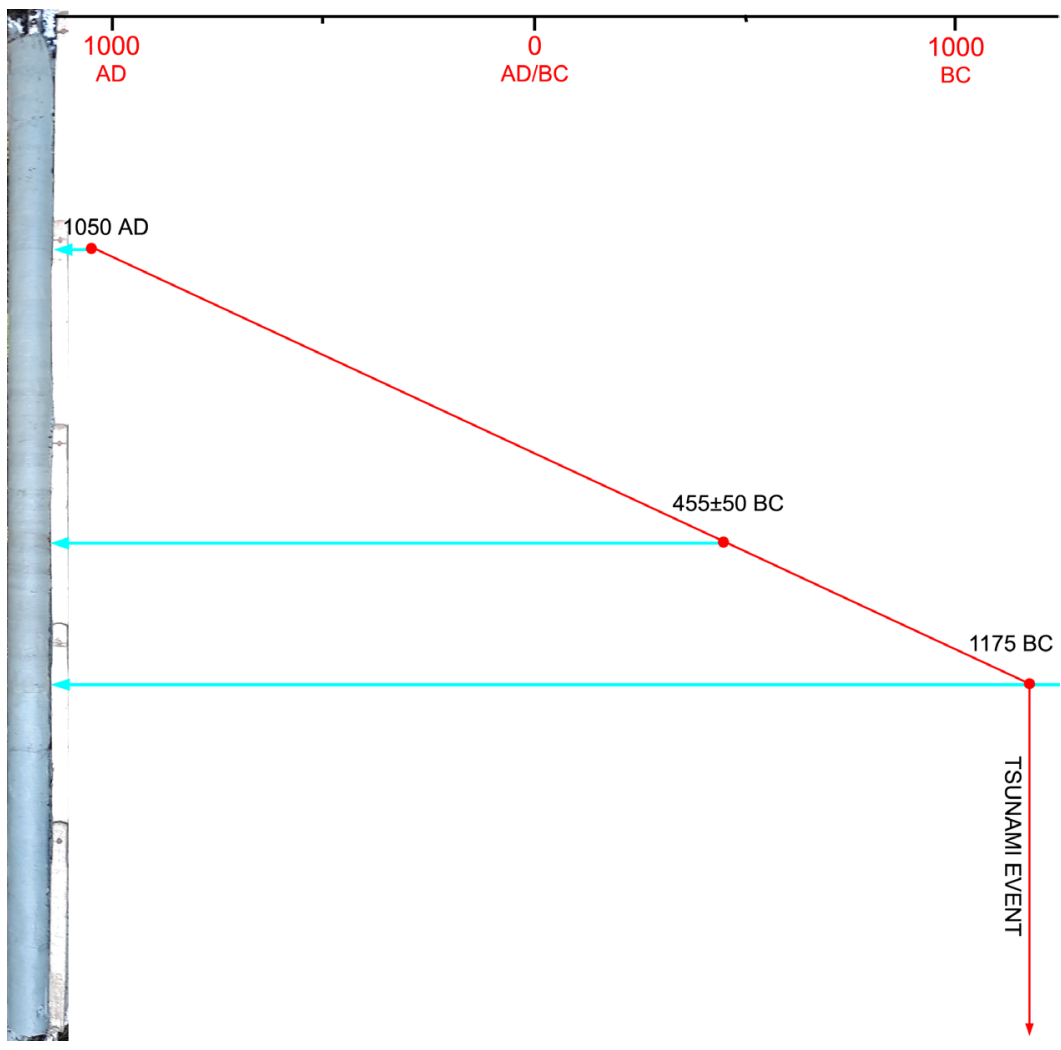

Figure 15. Site $S$ (Långarnö mosse) at about $+5 \mathrm{~m}$ with two fixed points: the date of the isolation from the Baltic at about $1050 \mathrm{AD}$ and the C14-date $455 \pm 50 \mathrm{cal}$. yrs BC and a sedimentation rate line, which dates the end of the tsunami deposition (fine clay) at 1175 BC. This age (though relative) agrees well with other dates of the tsunami event.

The C14-dates obtained from Sites Q and R (Figure 14) give far too old ages, which implies that they both represent reworked and redeposited organic matter (the ${ }^{13} \mathrm{C}$ values indicate brackish environment). The C14-date from Site $\mathrm{S}$ was $2396 \pm 29$ C14-years BP or $455 \pm 50$ cal. yrs BC, an age which corresponds to the climatic changes at the Sub-Boreal to Sub-Atlantic boundary; viz. a short period of intensive drought [31] followed by a general change to cooler and wetter climate conditions [32]. The site was isolated from the Baltic at about $1050 \mathrm{AD}$. A 2-point sedimentation rate graph is presented in Figure 15. It proposes that the tsunami ended at $1175 \mathrm{BC}$ at the fine clay/gyttja clay boundary, an age which corresponds well with other dates of the mega-tsunami event (Appendix).

\subsection{The Håbo Area}

In this paper, the Håbo area refers to the hilly area between the Ekolsundsviken Bay and the Ullfjärden lakes hosting the villages of Övergran, Yttergran and Bålsta (Figure 16). The Uppsala Esker passes on its eastern border. Two cores were taken in the southern lowland ( $\mathrm{Q}$ and R; Figure 14), four sites were cored in the central valley (T-X) and one $(\mathrm{Y})$ on the northern outlet side at the tsunami event (Figure 17). The area seems to have been quite densely populated in the Bronze Age with an archaeological key-site at Apalle (point 3 in Figure 16). 


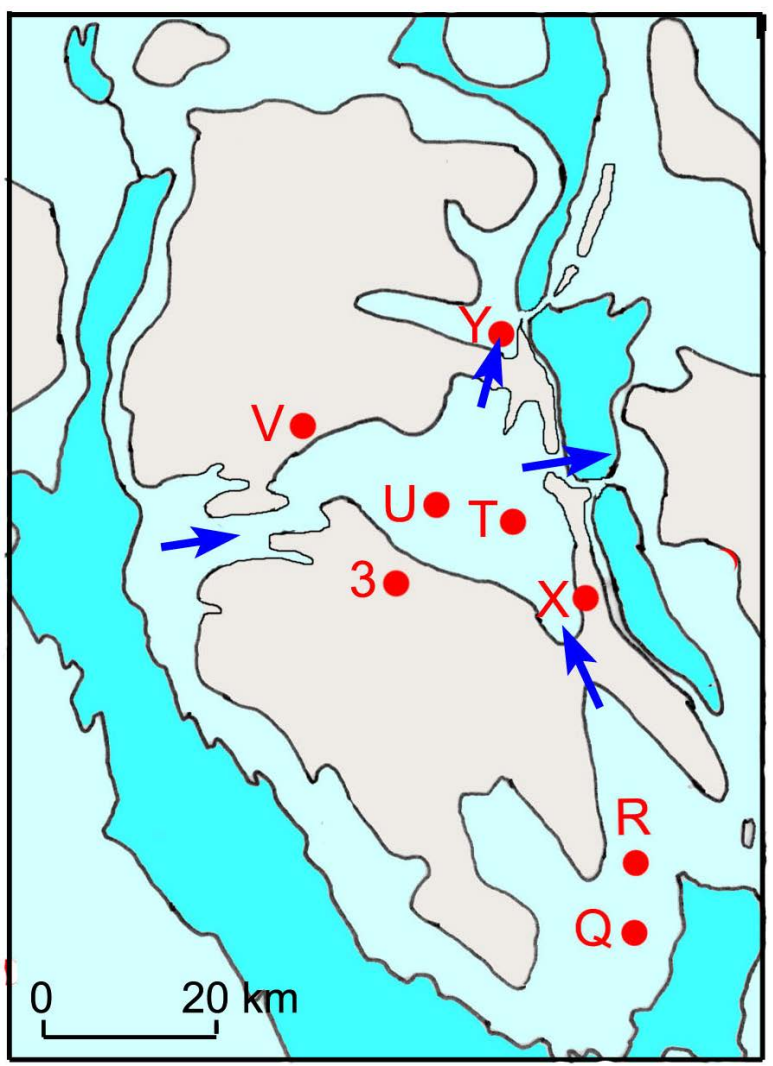

Figure 16. The Håbo area with core sites (T-Y), the Apalle site (3), the $+25 \mathrm{~m}$ contour and tsunami wave inlet (in the $\mathrm{W}$ and $\mathrm{S}$ ) and outlet (in the $\mathrm{N}$ and $\mathrm{E}$ ) areas.

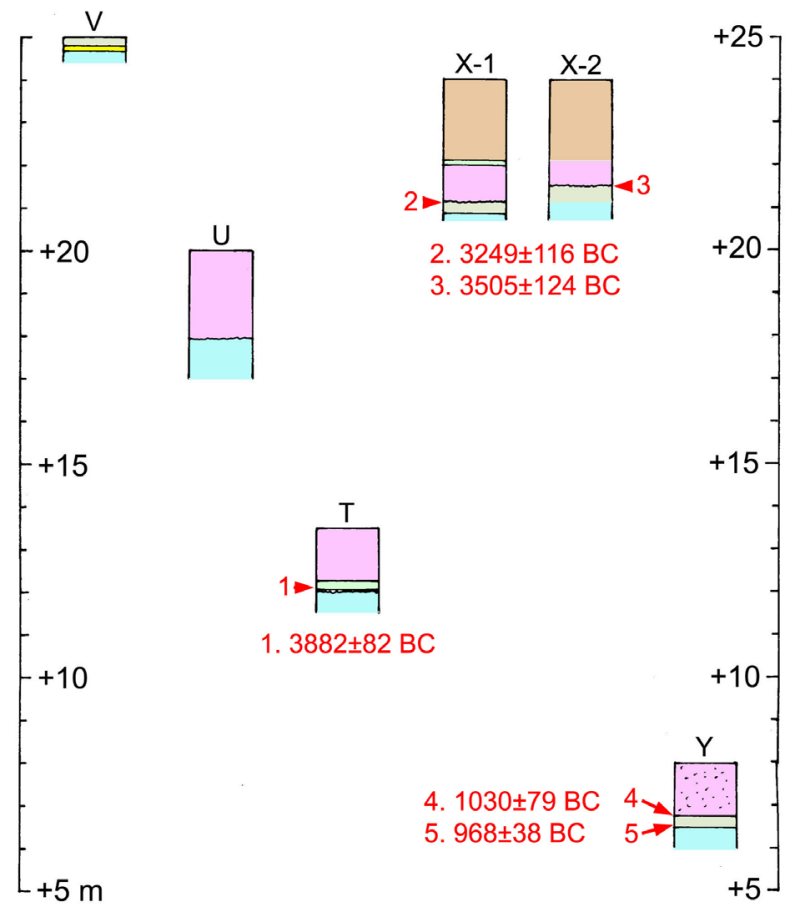

Figure 17. Stratigraphy and tsunami records in Cores T-Y in the Håbo area. 
The base of the central valley is at about $+13.5 \mathrm{~m}$, implying that a shallow lake was isolated in the area around Site T. This former lake stage is here called "Ancient Lake Gran" (Figure 18). It was more or less level with the sea at $+15 \mathrm{~m}$ at 3000 BP. The tsunami invaded the valley basin from the west (with threshold at about $+23 \mathrm{~m}$ ), the south (with threshold at about $+26 \mathrm{~m}$ ), and the east (with threshold in the order of $+15-20 \mathrm{~m}$ ). The tsunami seems to have over-washed the threshold in the north (at about $+27-28 \mathrm{~m}$ ). The main outlet of the collapsing water masses trapped within the basin must have escaped via the eastern outlet (Figure 16). Thick layers of fine clay in Sites T, U and X represent the settling of fine particles set in suspension by the tsunami wave. In Site $U$, the erosion has gone down into the glacial clay, leaving a hiatus of about 7000 years, indicating that the valley floor was swept clean of vegetation, soil and a substantial package of sediments.

Core $\mathrm{T}$ was taken in the middle of Ancient Lake Gran (Figure 18) and exhibits a key record in stratigraphy and chronology (Figure 19). It begins with a banded Baltic clay (probably a Littorina Sea clay, and not a glacial varved clay), which at its upper limit has an erosional surface cutting down into the clay. It is covered by $2.5 \mathrm{~cm}$ of gyttja silt representing the base of a tsunamite. It is covered by $19.5 \mathrm{~cm}$ gyttja and clay gyttja, and finally $127.5 \mathrm{~cm}$ of fine clay (from the settling of suspended particles in later phase of the tsunami event). The question is what the gyttja bed represents; 1) a normal lake sequence or 2) the final part of an initial tsunami phase of graded bedding starting with an erosion surface and followed by gyttja silt, gyttja and clay gyttja. The second alternative is here proposed.

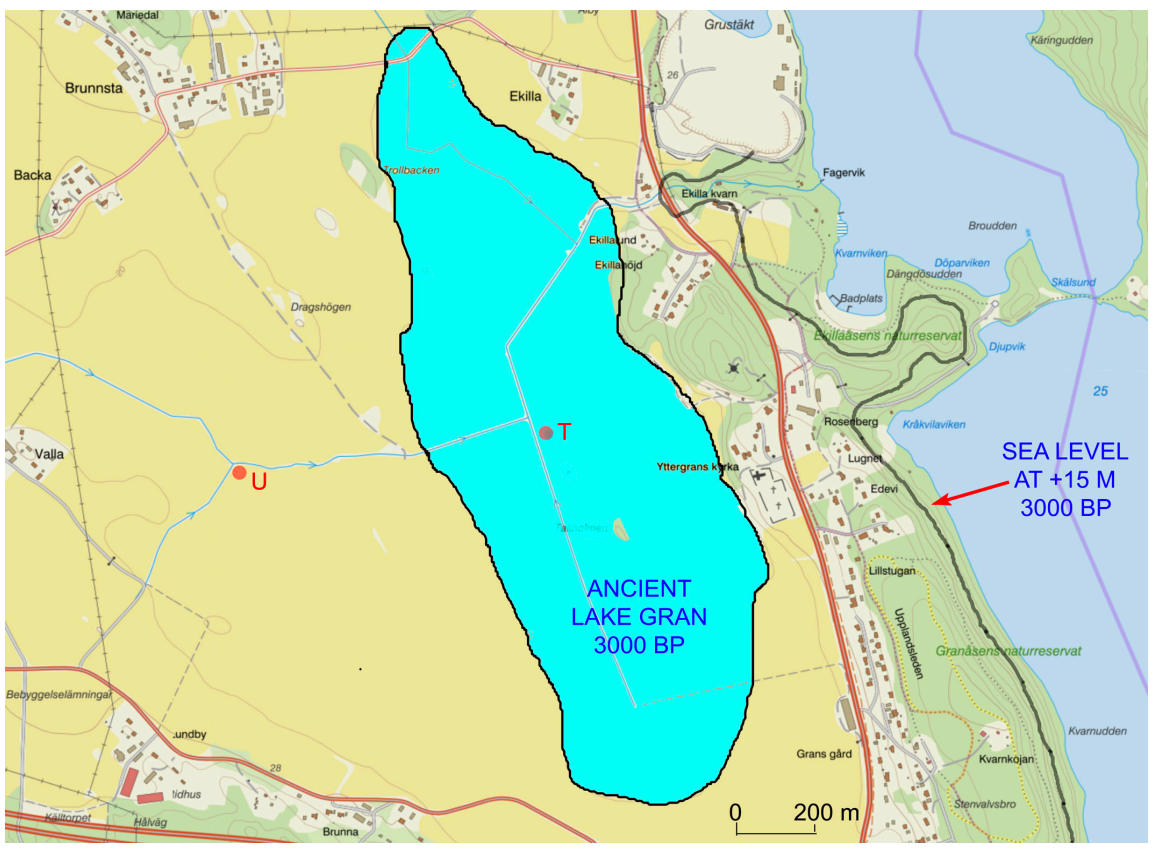

Figure 18. A local lake, termed “Ancient Lake Gran”, was isolated between the valley and the esker when sea level was at $+15 \mathrm{~m}$ at about $3000 \mathrm{BP}$, when the tsunami event took place. 


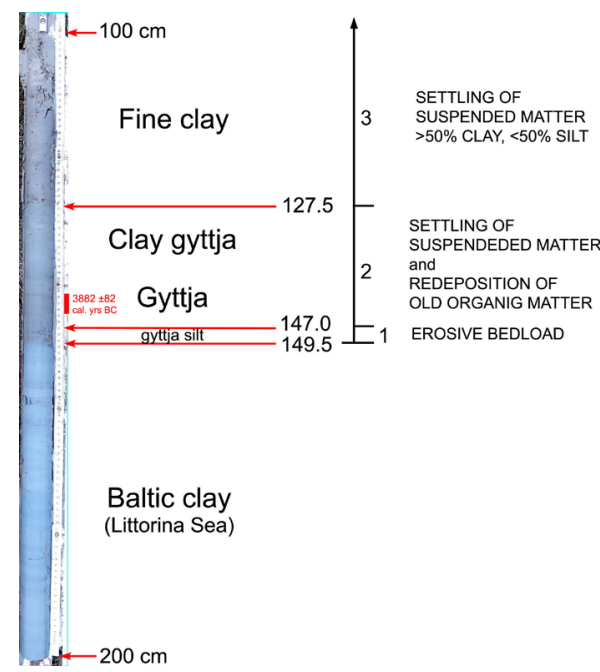

Figure 19. The Core T stratigraphy and chronology with a 3-parted tsunamite (arrow).

The tsunami at Site T (Figure 19) starts with erosion of the seabed surface followed by the deposition of $2.5 \mathrm{~cm}$ silt (bedload), $19.5 \mathrm{~cm}$ of gyttja and clay (a mixture of re-deposition of organic matter and setting of suspended particles) and $127.5 \mathrm{~cm}$ of fine clay (representing the settling of suspended particles). Gyttja $2-5 \mathrm{~cm}$ above the silt layer was C14-dated at $5113 \pm 31 \mathrm{BP}$ or $3882 \pm 82 \mathrm{cal}$. yrs $\mathrm{BC}$ (indicating the re-deposition of older reworked material). This means that the upper $149.5 \mathrm{~cm}$, in fact, represents one huge tsunamite divided into 3 parts of bedload transport and settling of suspended particles in a mega-graded-bedding unit (black arrow in Figure 19).

Site $\mathrm{X}$ refers to an overgrown dead-ice basin, where 3 cores were taken (Figure 20). The bog surface is at about $+24.0 \mathrm{~m}$. The surrounding slopes are about $10 \mathrm{~m}$ high. The inlet threshold is about $+25-26 \mathrm{~m}$. The cores (Figure 21) indicated that the tsunami invaded this basin, that settling suspended matter filled the basin, and that the whole basin was rapidly overgrown into a peat bog (up to $2.0 \mathrm{~m}$ thick) in post-tsunami time.

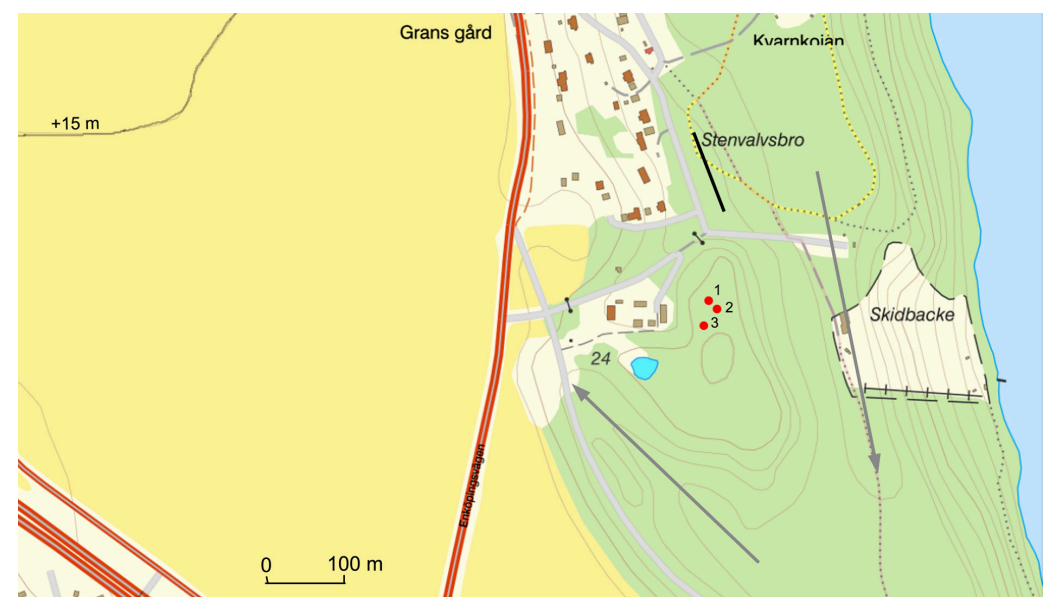

Figure 20. Location of the dead-ice basin where cores X-1 to X-3 were taken (red dots). Grey arrows indicate shore transport at the $+45 \mathrm{~m}$ and $+35 \mathrm{~m}$ sea level positions. 

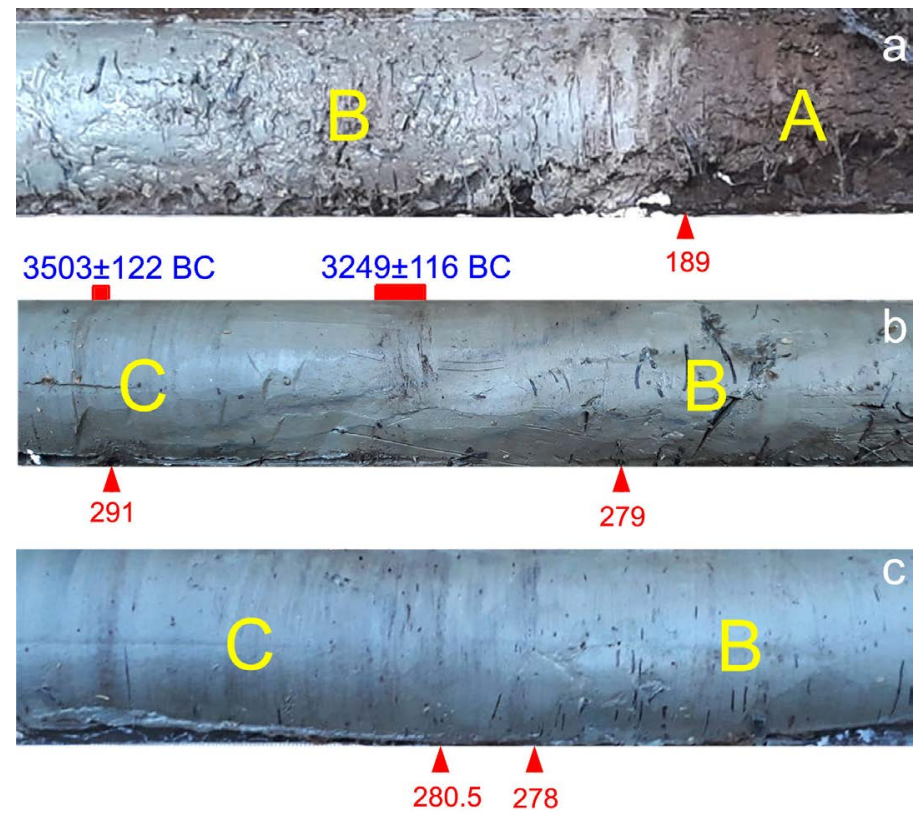

Figure 21. Core segments from the dead-ice hollow in the esker, filled with $1.9 \mathrm{~m}$ of peat (A), about $1 \mathrm{~m}$ of fine clay (B) from the tsunami wave, and Baltic clay (C) with a strongly eroded surface: $12 \mathrm{~cm}$ unconformity in (b) and $2.5 \mathrm{~cm}$ irregular layer in (c). The peat rests on a dried and fractured clay surface $1.9 \mathrm{~m}$ down (a). Cores X-1 (a, b) and X-2 (c). Dates in cal. yrs BC.

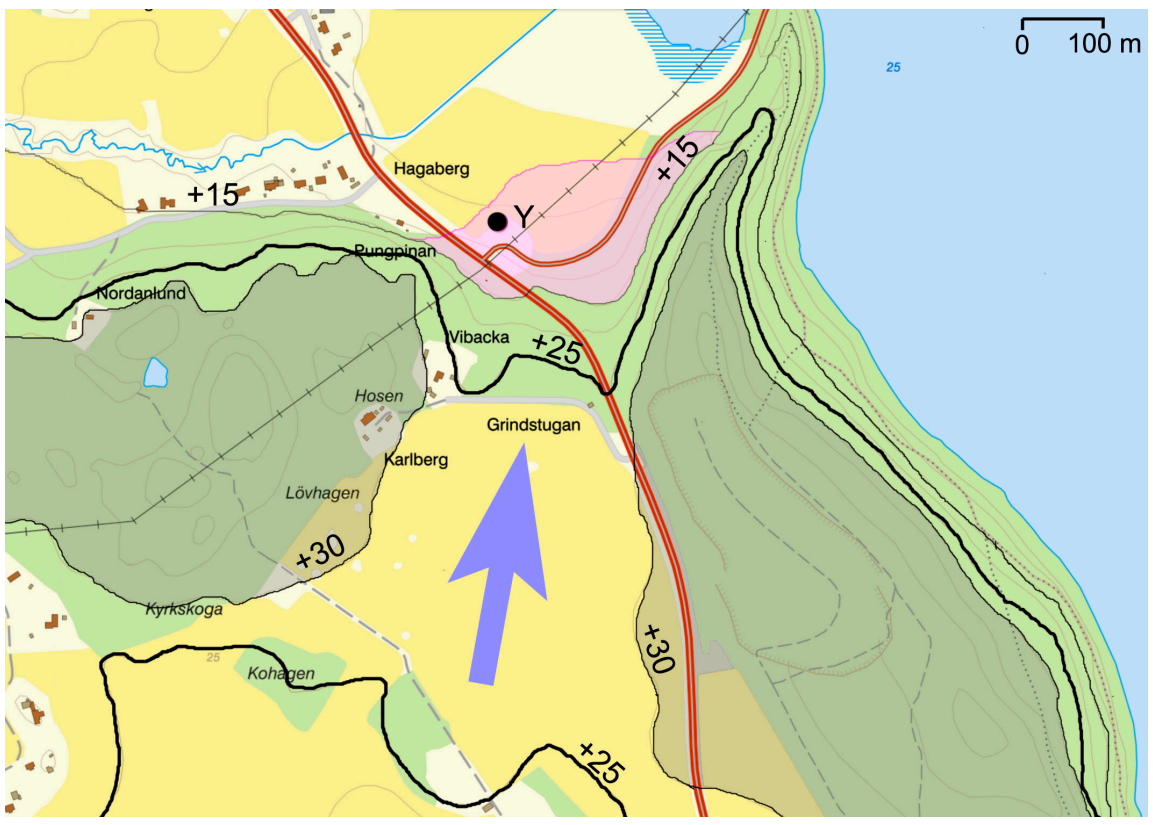

Figure 22. The tsunami outlet area to the north with a threshold at about $+27-28 \mathrm{~m}$ (blue arrow) and the deltaic accumulation of fine sand (bed-load) and fine clay (suspended matter) just outside the sea level at $+15 \mathrm{~m}$ at $3000 \mathrm{BP}$. Core $\mathrm{Y}$ records the stratigraphy.

In the north, the overflow threshold is at about $+27-28 \mathrm{~m}$ (Figure 22), and on the northern side the geological map [17] shows a wedge like layer of fine sand (violet field in Figure 22), which in view of the tsunami episode, might be 
the deposition of material from a violent overflow episode from the south (blue arrow in Figure 22). Core $\mathrm{Y}$ was therefore taken in the wedge (Figure 23), and, indeed, it shows $1.25 \mathrm{~m}$ of alternating fine sand (from tsunami bedload) and fine clay (from the tsunami suspended matter).

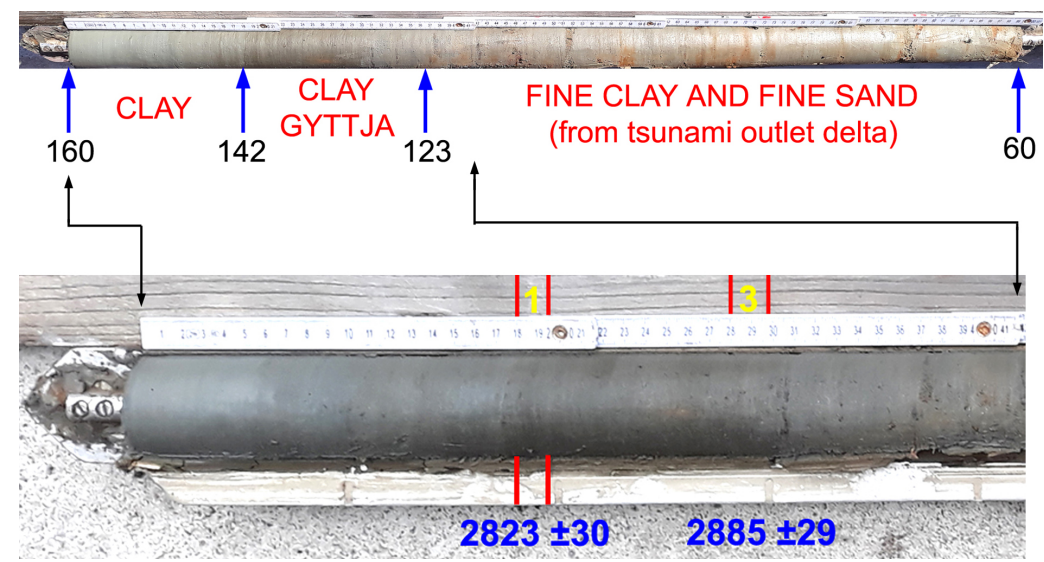

Figure 23. Core $\mathrm{Y}$ from the deltaic fine sand wedge associated with the $+15 \mathrm{~m}$ shore level just north of the tsunami overflow area to the north (Figure 22). The deltaic deposits are $125 \mathrm{~cm}$ thick and consist of fine clay (from the particles in suspension) and fine sand (from the bedload at the overflowing of the outlet threshold).

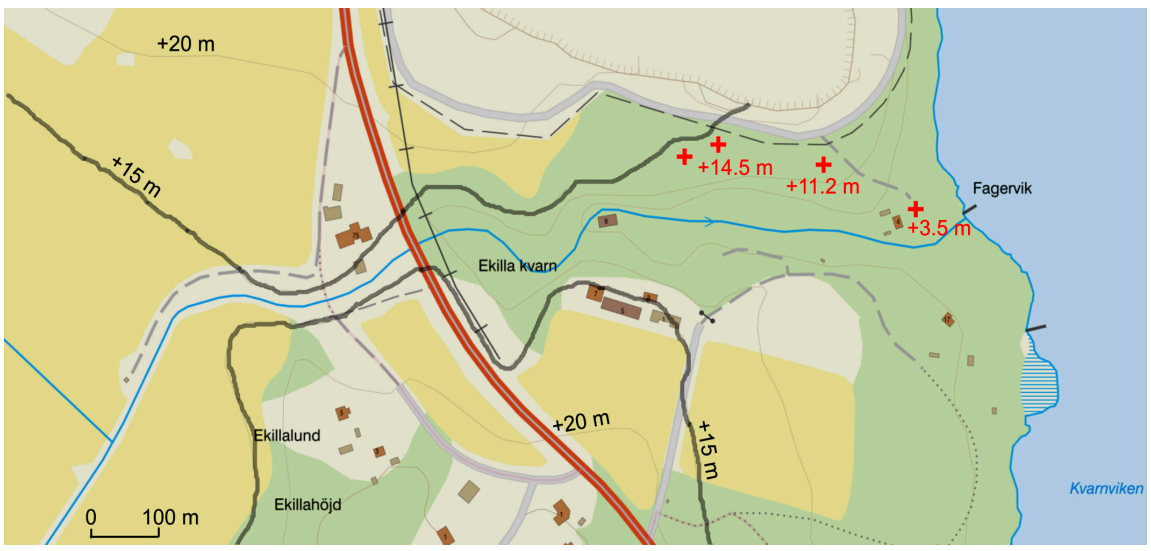

Figure 24. The main outlet in the east. At $3000 \mathrm{BP}$ sea level was at $+15 \mathrm{~m}$, and a separate lake was isolated in the Yttergran valley basin (Figure 18). After the tsunami invasion of the valley, the water masses must primarily have escaped via this outlet. The terrace plane at $+14.5 \mathrm{~m}$ fits well with a sea level at $+15.0 \mathrm{~m}$.

The main $+15 \mathrm{~m}$ outlet of the valley in the east is a deep erosional gauge (Figure 24). Prominent depositional terraces were leveled at $+14.5 \mathrm{~m},+11.2$ and $+3.5 \mathrm{~m}$. The $+14.5 \mathrm{~m}$ terrace fits with a sea level at $+15 \mathrm{~m}$ at the time of the tsunami, which must have had a violent outflow here.

The western inlet area (at the village of Krägga), the strong forces of the tsunami wave are seen in the eastward fingering of the $+25 \mathrm{~m}$ contour (Figure 16). One valley points directly to the Apalle area, where traces of the tsunami wave are seen up to $+31.5 \mathrm{~m}$. 


\subsection{The Apalle Archaeological Site}

Apalle is an archaeological site from the Bronze Age, about $350 \times 70 \mathrm{~m}$ (NW-SE), with an unusually thick, complex cultural layer [16] in the cultivated fields surrounding a crest with bedrock outcrops that reach above $+31 \mathrm{~m}$. This site is interesting to reconsider, both geologically and archaeologically.

Excavations in the later 1980s revealed a cultural layer over, under and between 79 house foundations, with post holes, hearths, clay flooring, two cultivated plots and eleven artificial wells. The settlement existed between the late Neolithic and the early Iron Age, with two main phases: the early Bronze Age and the latest Bronze Age-earliest Iron Age [16]. We note that the tsunami even occurred right in between those two main phases.

The Apalle monography [16] did not use stratigraphic units (i.e. chrono-stratigraphy) but "types of layers" (i.e. layers without stratigraphic order) as illustrated in Figure 25. This leads to dialectics between the original description [16] and the character of some layers in Figure 25. We have not been able to resolve this even among ourselves, so we leave it for a future revision. In Figure 25 , the geological suggestions (NAM) are expressed, however, for the sake of possible tsunami identifications.

The stratigraphy begins with a normal regression sequence from Baltic clay (layer 9) to littoral shore sand (8) and a land-surface with remains of vegetation (6) dated at $3140 \pm 110 \mathrm{BP}$ or $1390 \pm 130 \mathrm{cal}$. yrs BC. This date surely pre-dates the tsunami event.
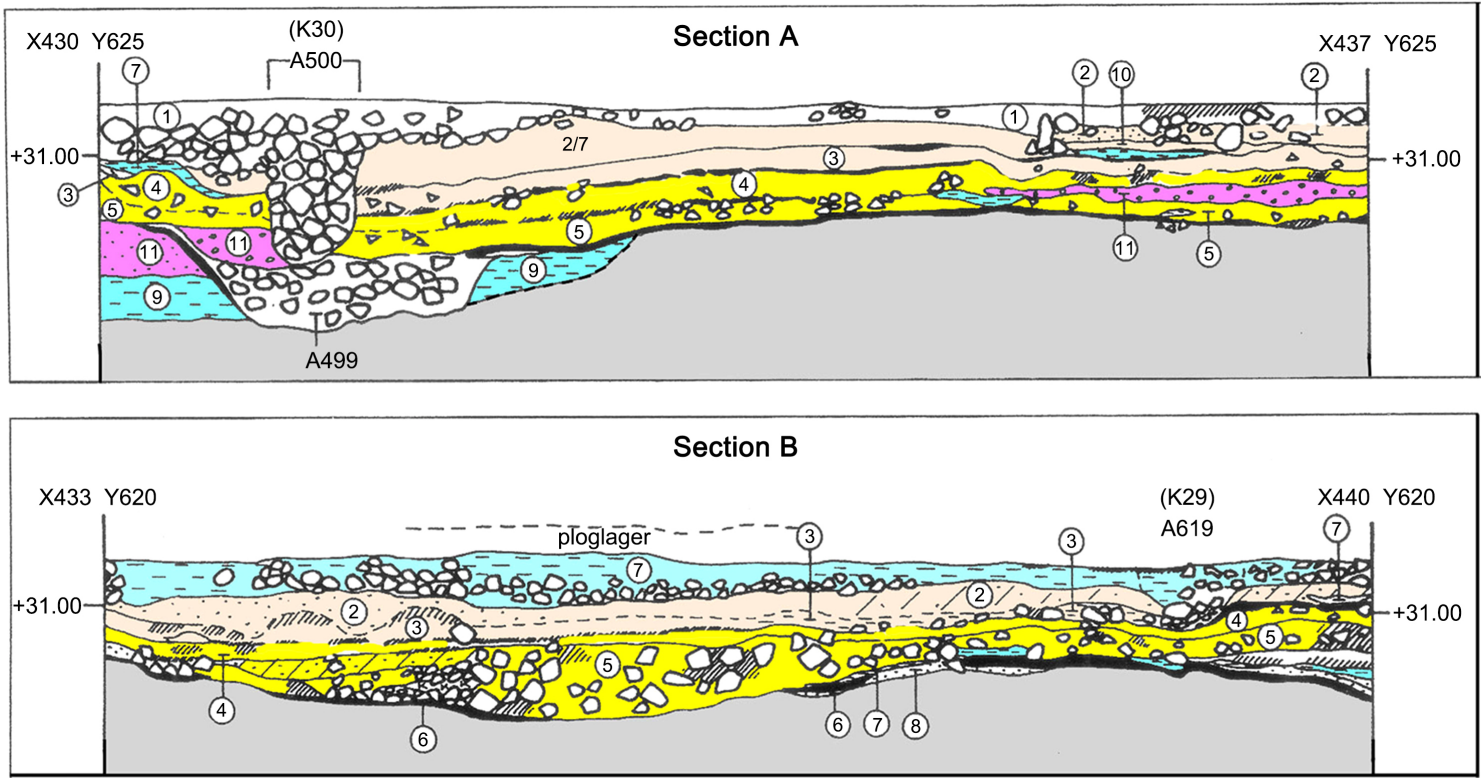

Figure 25. Stratigraphy at Apalle [16] with geology-based reinterpretation in terms of the re-deposition at two successive tsunami waves (marked yellow and tan). The Layer 6 land surface (1390 \pm 130 cal. yrs BC) pre-dates the tsunami. Layer 11 is a "till" containing "gravel and cultural remains". This indicated re-deposition under strong currents: we propose the tsunami. Layer 7 at the top of Section B is our problem. Clay mixed with pebbles and stones sounds like a typical tsunami deposit (the later phase with fine clay deposition). Chronologically it is held to be younger, however [16]. 
The material covering the old land-surface is very complex (Figure 25). The tsunami event seems to open new and logical interpretations, however. But there remains a lot of work to be done with respect to chronology [16] and strict correlation among radiocarbon dates and layer types. This will become an interesting challenge for future work.

At this site, the tsunami run-up must have reached $+31.5 \mathrm{~m}$ (Figure 25), which is higher than at Annelund $(+28.5 \mathrm{~m})$ and Boglösa $(+29.5 \mathrm{~m})$. The run-up level of a tsunami wave is not something fixed in elevation, rather it varies greatly with respect to exposure, shore configuration and possible interference of separate waves (in this case waves from the west and from the south). Therefore, it is concluded (NAM) that the tsunami wave must have reached up to $+31.5 \mathrm{~m}$ here at Apalle.

Several houses and wells were excavated [16] [33] (Figure 26). The wells were dug in clay. Tree branches were pushed down around the edges to keep the clay in position. Three of those were dated: $3110 \pm 30 \mathrm{BP}$ or $1379 \pm 42 \mathrm{cal}$. yrs BC in well A1992, $3090 \pm 65$ BP or $1354 \pm 73$ cal. yrs BC in well A1640, and $3045 \pm 55$ $\mathrm{BP}$ or $1303 \pm 77 \mathrm{cal}$. yrs BC in well A1514. All the 3 dates should pre-date the tsunami. The 3 dates overlap in the zone of 1338 to 1380 cal. yrs BC $(1351 \pm 21$ $\mathrm{BC}$ ), which provides an important date of the period preceding the tsunami event.

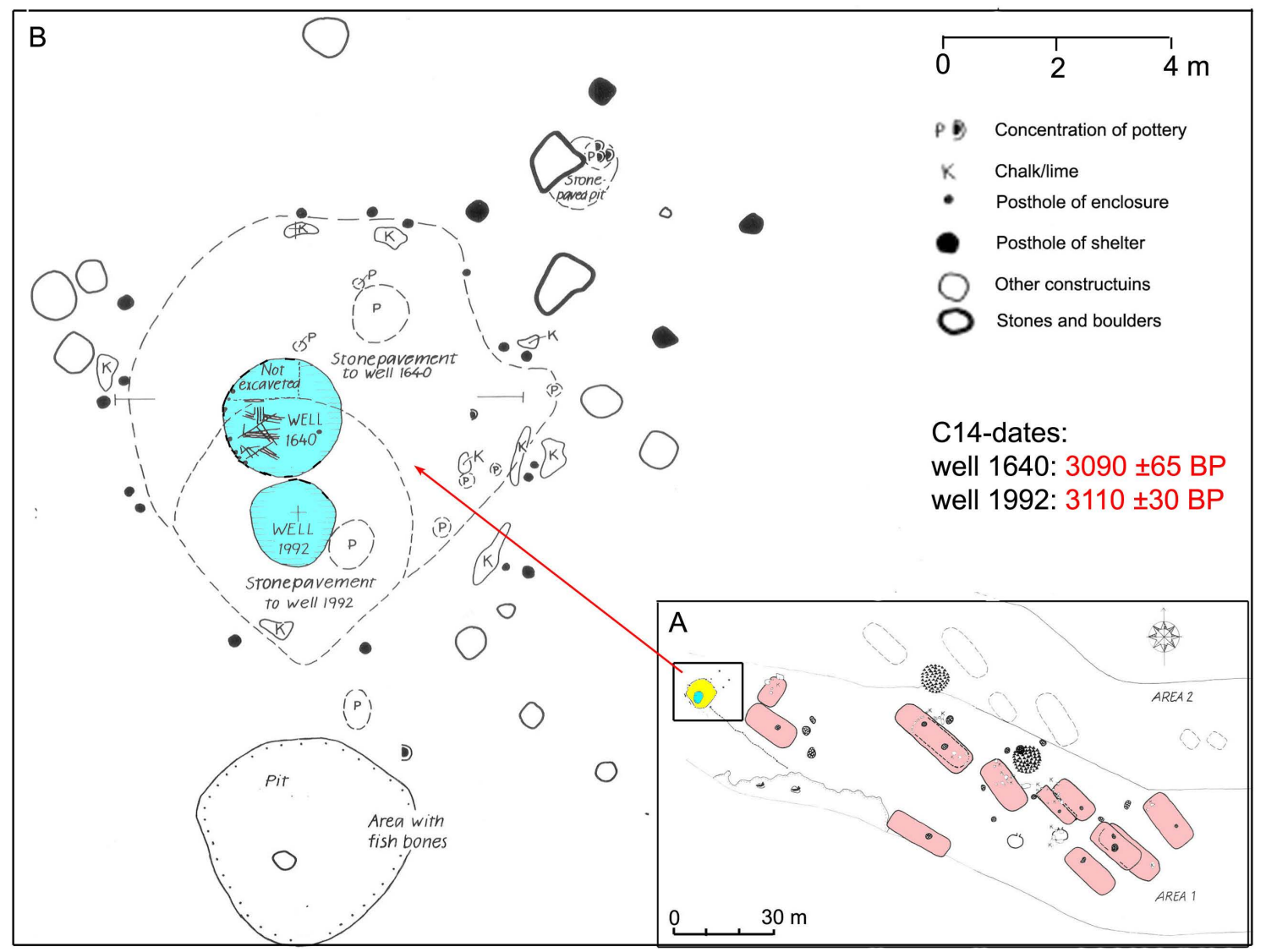

Figure 26. Location of houses (violet) and wells (blue) at Apalle (redrawn from [32]). 


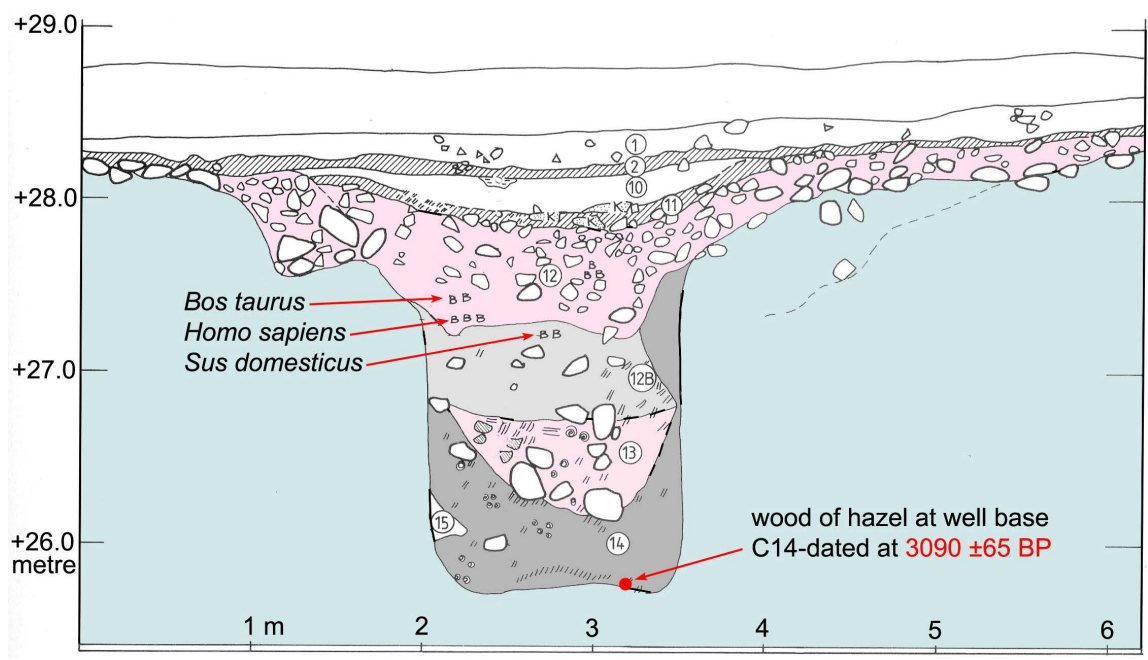

Figure 27. Well A1640. The well was dug at about $3090 \pm 65$ BP or $1354 \pm 73$ cal. yrs BC.

The wells are filled by "clay and anthropogenic material" according to [33]. Figure 27 gives the stratigraphy of well A1640. Layer 14 (the first layer to fill the well) is "clay rich in wood remains and with occasional stones". Layer 13 is "clay with brittle-burned stones, charcoal and wood remains". Layer 12B is "a clay layer with occasional stones and cultural remains". Layer 12 is "clay with cultural remains, stones and bones" (including a human bone). This looks far from a natural filling. The alternations between more clayey layer (14 and 12B) and layers of more cultural remains and stones are proposed to represent the overflowing of the well by two successive tsunami waves both including a running-up phase (14 and 12B) and a swashing-back phase (13 and 12) drawing down material from the surroundings (including one human bone together with bones of cow and pig). Layer 11 post-dates the tsunami.

From the elevation (Figure 27), it is clear that the tsunami must have reached, at least, up to $+28.5 \mathrm{~m}$ (in order to flood well A1640), which is in full agreement the records from Annelund, Boglösa and the coring in the Håbo area.

It seems significant that pollen analysis of the well A1640 sequence lack signs of progressive development, unlike the continual development recorded in a progressively infilled well from the Iron Age [34] [35].

Ullén [16] recognized 54 houses (43 separate houses according to [36]), which she arranged in 5 phases of housing with related activities (wells, burnt mounds, farming, etc.). With a contemporaneous tsunami event, things become complicated, however. Below follows a geological based (NAM) interpretation of the material presented [16].

Phase 1 includes 2 houses. There are two dates from house K10: soot dated $3055 \pm 60 \mathrm{BP}(1310 \pm 79$ cal. yrs BC$)$ and a food crust on a jar fragment dated $2835 \pm 50$ (1010 \pm 72 cal. yrs BC). This means a difference of about 300 years, which seems questionable. The jar fragment with a food crust was obtained below "the clay floor", considered to be human made. If the clay comes from the tsunami, however, things seem more logic. There was an early house with an age 
of about $3055 \pm 60 \mathrm{BP}$ or $1310 \pm 79 \mathrm{cal}$. yrs BC. Then came the tsunami and flooded the area and deposited the jar fragment in a layer of clay, which would give an age of the tsunami of about $2835 \pm 50$ or $1010 \pm 72$ cal. yrs BC (Appendix).

Houses K9 and K27 overlap each other. Between the house remains there is a clay floor of $4 \mathrm{~m}$ (double the size of the houses), which may represent a tsunami deposit (Figure 31 in [16]). Unfortunately, the houses are undated.

Phase 2 includes 10 houses and 5 dates ranging from 3110 to $2970 \mathrm{BP}$ (mean: $3030 \pm 40 \mathrm{BP}$ ) or from 1360 to $1195 \mathrm{BC}$ (mean: $1268 \pm 80$ cal. yrs BP). This house phase is likely to pre-date the tsunami.

Phase 3 includes 12 houses and 6 dates: house K28 dated at $2880 \pm 60 \mathrm{BP}$ (1080 \pm 94 cal. yrs BC), K30 dated at (mean of 4 closely spaced dates) $2853 \pm 65$ BP (1053 \pm 60 cal. yrs BC) and house K16 dated at $2780 \pm 60 \mathrm{BP}(939 \pm 71 \mathrm{cal}$. yrs BC). The phase 3 houses are likely to post-date the tsunami. Phase 4 including 12 houses and 7 dates six closely spaced and one outlier of high uncertainty) has a similar age: $2819 \pm 40 \mathrm{BP}(993 \pm 40 \mathrm{cal}$. yrs BP). Phase 5 (12 houses and 10 dates) is surely younger that the tsunami, dating from 2900 to 2500 BP (2660 \pm 140 BP or $791 \pm 196$ cal. yrs BC).

In conclusion, this means that the Apalle Sections A and B establish a tsunami run-up of about 16 meters, based on a contemporary shoreline level $+15 \mathrm{~m}$. The evidence seen in the wells, establishes a necessary run-up of a minimum of 13.5 meters. This coincides well with the data from the Annelund site, the Boglösa area and the coring in the Håbo area. A comparison of available C14-dates is given in (Appendix).

\subsection{The Western Part of the Lake Mälaren Area}

Theoretically, the tsunami might have reached all the way in to Örebro (Figure 4). With the new tool of a mega-tsunami event at about $3000 \mathrm{BP}$, it seems urgent also to revisit geological and archaeological sites in the entire Lake Mälaren region (Figure 4). Lake Hjälmaren has a present level of $+21.8 \mathrm{~m}$ (drained by about 1.3 $\mathrm{m}$ in 1878-1887), so even this region might have been affected by the tsunami. We have investigated the map description and relevant literature of the area without finding any firm records of the Lake Mälaren 3000 BP mega-tsunami here described.

The tsunami wave-height is likely to decrease with distance inland. In the Enköping-Bålsta area a run up of 13.5 to $16.5 \mathrm{~m}$ (the wave reaching 28.5 to $31.5 \mathrm{~m}$ ) is well established. Further westwards, the situation is still unexplored, however.

Southeast of Västerås [19] and between Strängnäs and Eskilstuna [20] there are records of fine clay resting upon gyttja clay including sand from bedload deposition as mentioned above (and marked with red dots in Figure 4).

Robertson [37] made a study of the shore-level displacement based on the isolation of lake basins at different elevations in the Eskilstuna area. She met problems in the dating of isolation basins in the +24 to $+35.7 \mathrm{~m}$ level. The isolation of Fågelmossen at $+35.7 \mathrm{~m}$ was dated (C14-ages) at $3850 \pm 130 \mathrm{BP}$, Fräksmyren at $+31.1 \mathrm{~m}$ at $4135 \pm 70 \mathrm{BP}$, Janslunda at $+29.3 \mathrm{~m}$ at $4225 \pm 110$ and right below 
$4045 \pm 70 \mathrm{BP}$ (i.e. in reversed order), Stormossen at $+28 \mathrm{~m}$ at about $4400 \mathrm{BP}$, and Borsökna sjön at $+24 \mathrm{~m}$ at $4290 \pm 195$. These are, of course, impossible dates as it would imply that basins at $12 \mathrm{~m}$ difference in elevation would all have been isolated at about $4100 \mathrm{BP}$ and in a nearly opposed sequential order. Besides, all dates were old "whole-sediment" dates before the AMS-dating technique.

The Janslunda bog (at $+29.3 \mathrm{~m}$ ) was cored in May, 2020 (our Site Z). The original paper [37] included some points that seemed open for reconsideration, viz.: 1) a $3 \mathrm{~cm}$ "sandy gravel" at the boundary between gyttja clay and Baltic clay (which sounded like a tsunamite), 2) the occurrence of a $51 \%$ peak of planktonic brackish-marine diatoms in the gyttja clay above (which usually is a criterion to identify a tsunami bed [7]), and 3) the inconsistencies of the C14-dates which opened for a revision.

The new core taken (Figure 28) records a deep erosion (irregular and sand filled) going down into grey clay (maybe of the Ancylus lake stage), implying a hiatus of about 6000 years.

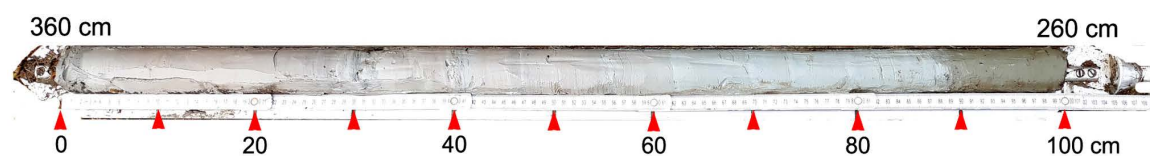

Figure 28. Core Z, Janslunda bog, segment $360-260 \mathrm{~cm}$ down: $62 \mathrm{~cm}$ a pinkish glacially varved clay, $26.5 \mathrm{~cm}$ of grey clay (maybe varved), about $1.5 \mathrm{~cm}$ erosion surface and tsunami sand, and about $10 \mathrm{~cm}$ of gyttja-clay and gyttja (with details in Figure 29).

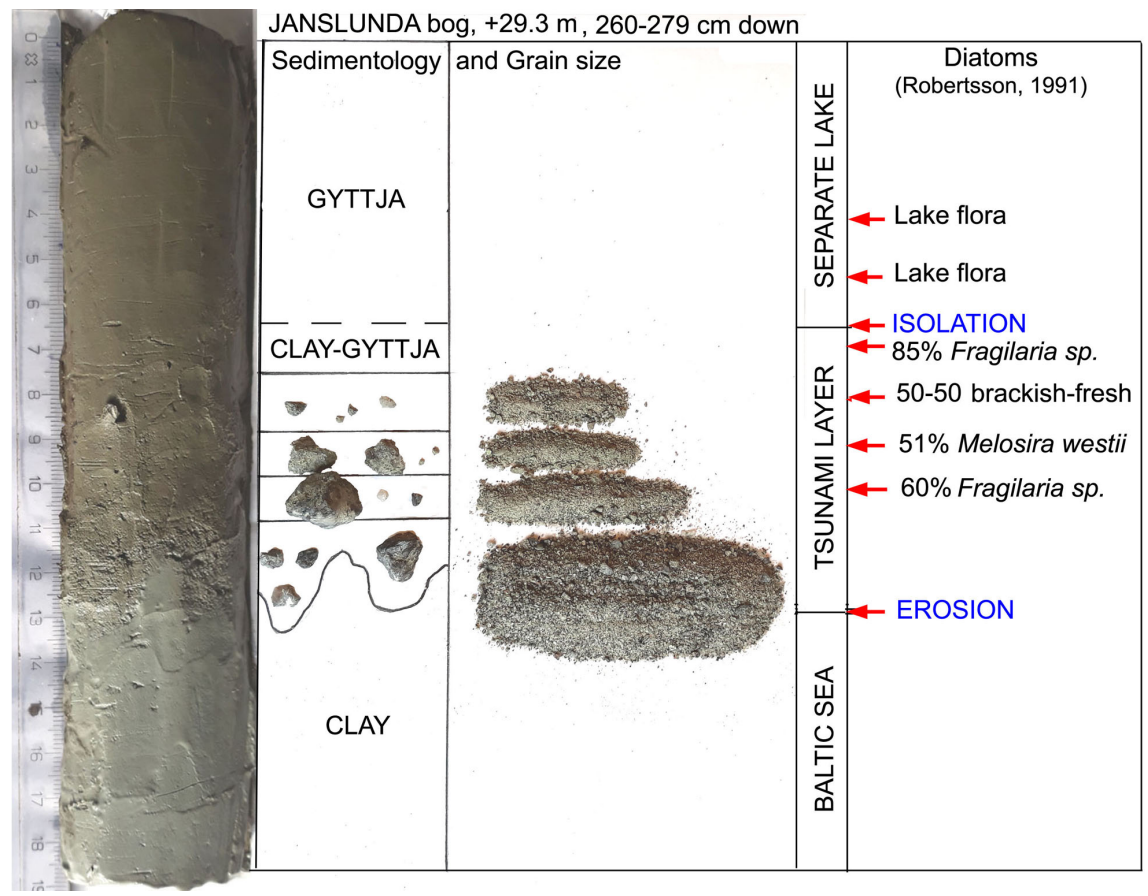

Figure 29. Janslunda bog, core Z, 260 - $279 \mathrm{~cm}$ shown with stratigraphy, grain size records, and diatom analyses inferred from [37]. A tsunami event generated extensive erosion of the under-laying clay (removing about 6000 years of sediments) and depositing a tsunamite consisting of two units: a lower unit of unsorted sand with angular grits of fine gravel an upper unit of gyttja fine-clay including silt and angular grits of sand and gravel. 
The irregular erosions surface (Figure 29) is covered by $1.0-2.5 \mathrm{~cm}$ of sand including grits of fine gravel and coarse gravel that lack signs of rounding excluding a littoral deposition; rather an instantaneous and violent tsunami deposition. This bed has all the characteristics of a tsunami bed. The covering $3.3 \mathrm{~cm}$ consists of gyttja-clay (fine clay) with silt and angular grits of sand and gravel (even coarse gravel). This unit can only have been formed due to a mixture of violent bedload deposition and settling of suspended material. The covering 0.7 $1.0 \mathrm{~cm}$ of fine-clay-gyttja seems to represent the final part of the unit with only the settling of suspended gyttja and clay matter.

The diatom flora (as measured at 6 levels by [37]) can now be understood in other terms: 1) $60 \%$ Fragilaria sp. $+28 \%$ brackish to brackish-marine species represents a mixed flora dominated by reworked material, 2) 51\% of Melosira westii, a planktonic brackish-marine species, fits the characteristics of tsunami deposits [7], 3) a mixture of $50 \%$ of both brackish and freshwater species seem to mark the later phase of the tsunami, 4) 85\% Fragilaria sp. implies final setting of suspended material close to the isolation contact, and (5 - 6) represent full lacustrine conditions.

The recording of the mega-tsunami tsunami event seems now firmly fixed in Figure 29. It represents a tsunami wave height of at least $14.5 \mathrm{~m}$, which implies that Lake Hjälmaren $(+24 \mathrm{~m})$ must also have been invaded by the tsunami. A record of this seems to occur in Ullavisjön (Magnusson, 1970), but we were not able to document this by coring at the site.

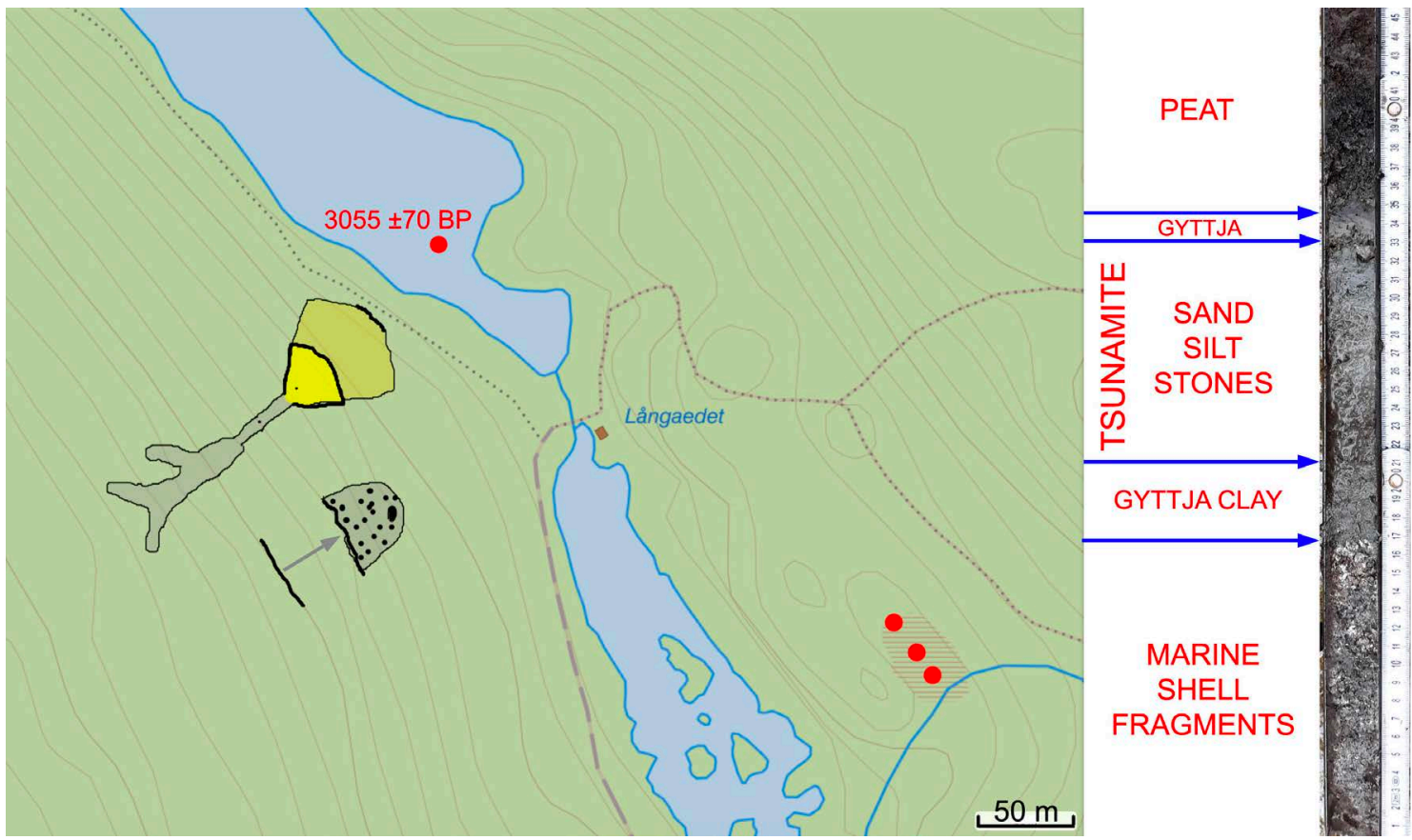

Figure 30. The Långaedet area and the Lower and Middle Lake Marviken. Three sediment cores were taken in a small bog at $+29.5 \mathrm{~m}$ (red dots) and the core obtained (right) with a clear tsunami layer. In the valley side to the west, there is a big earth slide and an erosional gully ending in an alluvial cone (yellow) with its inner apex at +34 $\mathrm{m}$, its break-in-slope at $+26 \mathrm{~m}$ and its foot at $+17.7 \mathrm{~m}$, just above the shore at $+15 \mathrm{~m}$ at the time of the tsunami. 


\subsection{The Åker-Långaedet Area}

The area is traversed by an old fracture zone, now occupied by a system of lakes: the Lake Marviken lake system. The word "marviken" goes back to "fractured" [25], and, indeed, the valley is characterized by fractured bedrock, fault movement, earth slides and methane venting tectonics [2] [22] [23].

Sediments cores in the lake record a tsunami bed over a distance of at least 6 $\mathrm{km}$. It is dated at $3055 \pm 70 \mathrm{BP}$ or $1303 \pm 91 \mathrm{cal}$. yrs BC. Previously, it was interpreted as a local lake tsunami generated by a slide [23]. Now, it seems obvious that it was contemporaneous with the mega-tsunami event recorded in the whole of the Lake Mälaren valley at about 3000 BP.

Therefore, the site was revisited in 2020. In a small bog at $+29.5 \mathrm{~m}$ (Figure 30 ), sediment cores were taken at 3 locations. A clear tsunami layer was recorded at a depth of about $1.5 \mathrm{~m}$ : i.e. at an elevation of about $+28.0 \mathrm{~m}$, indicating a tsunami run-up of at least $13.0 \mathrm{~m}$ (in full agreement with the data from the Enköping-Bålsta area.

There are also morphological criteria in the valley side to consider (Figure 31). In the valley slope, there is an erosional gully with back-erosion up the slope and with a sub-areal alluvial cone in front ending at $+17.7 \mathrm{~m}$ just above the shore of the $+15 \mathrm{~m}$ sea level at $3000 \mathrm{BP}$ (Figure 30). The apex of the alluvial cone is at $+34 \mathrm{~m}$ and the outer break-in-slope is at $+26 \mathrm{~m}$. The gully is assumed to have been formed by back erosion initiated by the tsunami run-up at about $+34 \mathrm{~m}$ due to narrowing of the valley and maybe also the interference of waves coming both from the southeast and the northwest. There is also a land slide ending at $+29 \mathrm{~m}$.

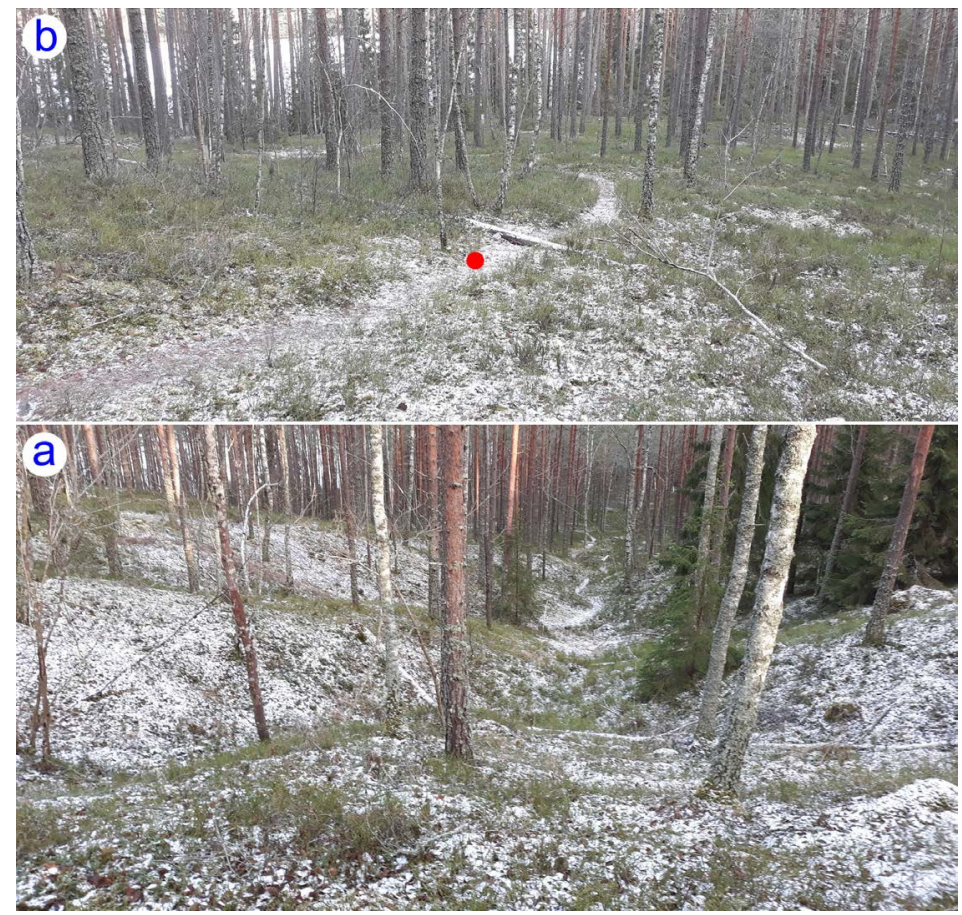

Figure 31 . The gully (a) with back-erosion in bird-foot shape, and (b) the alluvial cone below with its apex (red dot) at $+34 \mathrm{~m}$, the possible local run-up level of the tsunami here. 
The masses lost by back-erosion in the gully are in the same order of volume as the one of the alluvial cone. This erosion/deposition feature must have been initiated by changes in the water level at a time when sea level as at about $+15 \mathrm{~m}$ (below the foot of the alluvial cone).

The new data indicate that the tsunami was not local but a part of the Baltic-wide event occurring at about $3000 \mathrm{BP}$, and that the run-up was at least $13 \mathrm{~m}$ (at the core site) and maybe as much as $19 \mathrm{~m}$ at the gulley (Figure 30).

\subsection{Upplands-Väsby (Tolan)}

As a part of an archaeological investigation, we also undertook a geo-tectonic analysis of the Tolan site and Sandaskogen area ([24] and supplementary material to [11]). Obviously, the area had suffered severe ground-shaking. In lake Sandakärret at $+35.5 \mathrm{~m}$, a tsunami bed was recorded (in 3 cores) consisting of unsorted and angular grains. It was dated at $3073 \pm 33 \mathrm{C} 14$-yrs BP or $1315 \pm 85$ cal. yrs BP (in full agreement with other dates of the mega-tsunami). In order to reach into the lake basin, the tsunami-wave need to have had a run-up of $20.5 \mathrm{~m}$ (which is the highest value recorded).

Some $5 \mathrm{~km}$ to the south, Henkel [38] has described an earth slide over a clay field and deformed bedrock, which seems to correlate to the Tolan deformations.

\subsection{Saltsjöbaden}

A tsunami bed in Lake Dammsjön at $+24 \mathrm{~m}$ indicates a tsunami height of at least $9 \mathrm{~m}$ (rather 10 to reach over the outlet threshold). The site is described in the supplementary file to [11]. Cores taken at $+28-29 \mathrm{~m}$ did not have any visible tsunami layers. The bedrock steepness outside the threshold suggests that the run-up above tsunami wave-height was small to absent.

\subsection{Södertörn (Fituna-Kvarnberget)}

Kvarnberget is a type-site for methane venting tectonics (MVT) [11] [22] [26]. It is linked to the Fituna delta at $+15 \mathrm{~m}$ [11] [22] deposited at about $3000 \mathrm{BP}$ as a consequence of the tsunami event, the wave-height of which was estimated at a minimum of $10 \mathrm{~m}$.

\subsection{Tystberga}

Tystberga refers to some old sites investigated by Florin [39] with respect to sea level changes and archaeology. It is clear that his high-amplitude sea level changes were in need of revision. The tsunami event at Fituna on the Södertörn peninsula fits both in time and elevation [11] [22]. At Rogsta Hage in Tystberga, there is a section which seems to record a tsunami layer extending up to $+31 \mathrm{~m}$ (supplementary material to [11]). Therefore, we seem to be dealing with a $16 \mathrm{~m}$ tsunami run-up. 


\section{Varve Dating and Tsunami Records in Ångermanland}

At Umeå, the tsunami height was established at $11 \mathrm{~m}$ and at Hudiksvall at $12 \mathrm{~m}$ (Figure 1). As the River Ångermanälven area lies in between these two points, one might expect to also record the tsunami at River Ångermanälven. This area is interesting because here we have a chronology based on annual varve counting [40]. The original varve counting by Lidén [40] was not connected to the present, however. This connection was later successfully established by Cato [41] [42] [43]. The dataset consists of 16 varve dated deltas ranging in elevation from $+134 \mathrm{~m}$ to $+10 \mathrm{~m}$ and in time from $6072 \mathrm{BC}$ to $555 \mathrm{AD}$.

After a careful investigation of available data, it now seems possible to identify a significant tsunami event and provide an absolute date in terms of the Swedish varve chronology [42]. The effects of a mega-tsunami are revealed in the following three facts (as illustrated in Figure 32):

1) Site 16 is a terrace with its last varve dated $1165 \mathrm{BC}$, though it would have been at sea level at $600 \mathrm{BC}$ (i.e. ca 665 varves are missing). The terrace lies $7 \mathrm{~m}$ below the sea level at that time. It is covered by 7 sandy varves, which seems to represent a stratified tsunamite of $118 \mathrm{~cm}$ thickness (composed of two waves).

2) Site 9 is a terrace at $+46 \mathrm{~m}$ and has its last varve dated at $3086 \mathrm{BC}$, though it would have been at sea level at $2100 \mathrm{BC}$ (i.e. ca 986 varves missing). The terrace lies $14.5 \mathrm{~m}$ below the sea level at the time of the last varve. It is covered by a potential tsunamite.

3) The varve dates of Sites 10 to 13 are off-set by 120 - 200 years from the straight line of shore displacement (blue line in Figure 32).

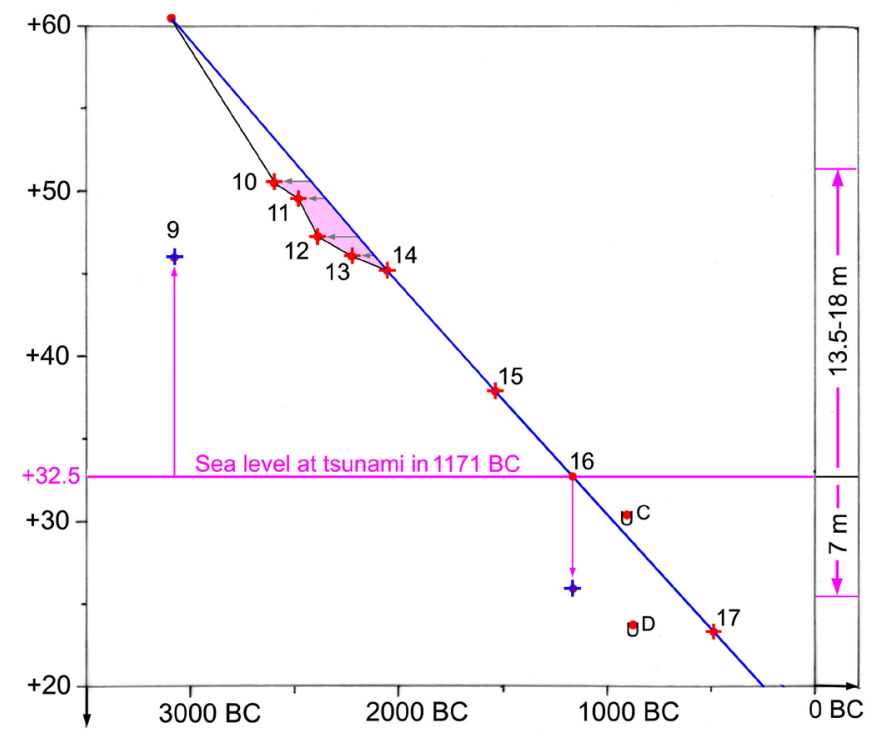

Figure 32. Ångermanland elevation/time plot based on data from [42]: blue line gives shore-level displacement, red plus-signs refer to varve dated deltas, blue plus-signs refer to terraces, red dot in a U refer to varve dated lake records [44] [45], purple line gives sea level at tsunami event $(+32.5 \mathrm{~m})$ and terrestrial run-up (Site 9), submarine bedload (Site 16), and run-up erosion at Sites 10 - 13. The tsunami seems to have had a total run-up of about 13.5 - $18 \mathrm{~m}$ and submarine erosion/deposition effects down to $-7 \mathrm{~m}$. 
I think we can now provide quite a firm interpretation. In the varve year 1171 $\mathrm{BC}$, the area was struck by a mega-tsunami. It deposited a $118 \mathrm{~cm}$ thick stratified tsunamite on top of the Site 16 terrace implying a submarine bedload deposition at a depth of $-7 \mathrm{~m}$. The same event had a run-up of at least $13.5 \mathrm{~m}$, eroding the top surface of the Site 9 terrace and depositing a stratified tsunamite of $688 \mathrm{~cm}$ (previously counted as 8 varves [42]) or (as shown in Lidén's original stratigraphic drawing, Figure 9 in [42]), a unit of $4.7 \mathrm{~m}$ consisting of 4 beds of gravel, which might represent a sequence of 4 tsunami waves (in analogy with the $10,430 \mathrm{BP}$ tsunami in southern Sweden consisting of 6 cycles of graded bedding in Figure 4 of [8]).

Site 10 misses about 200 varves and ends with 6 sandy varves of a total thickness of $801 \mathrm{~cm}$, Site 11 misses about 160 varves at the top and ends with 8 sandy varves of a total thickness of $431 \mathrm{~cm}$, Site 12 misses 200 varves at the top and ends with 5 sandy varves of a total thickness of $336 \mathrm{~cm}$, Site 13 misses 120 varves at the top and ends with 13 sandy varves of a total thickness of $1187 \mathrm{~cm}$, Site 14 lies on the blue line and ends with 2 sandy varves of a total thickness of $60 \mathrm{~cm}$, and Site 15 (on the blue line) ends with 7 varves of a total thickness of $169 \mathrm{~cm}$. These terminal sandy varves are likely to represent stratified tsunami beds as illustrated in Figure 33.

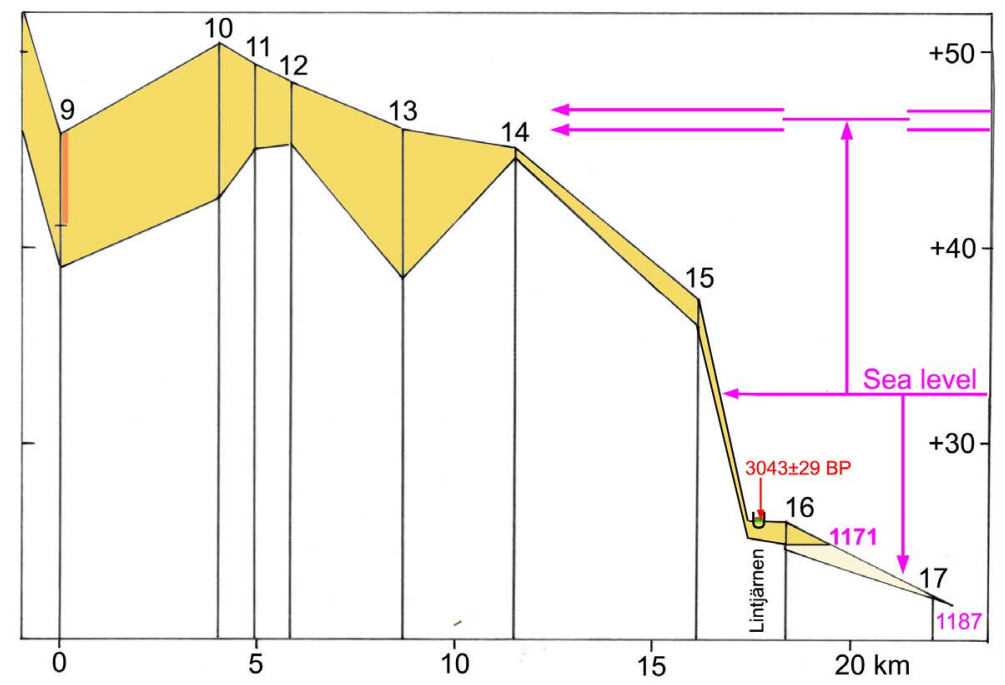

Figure 33. The varve sequences of Sites 9 - 13 end with thick sandy varves (yellow) that are likely to represent the effects of a tsunami event in a sequence of two to four separate waves. The tsunami run-up is likely to have had an amplitude of about $14 \mathrm{~m}$, reaching up to $+46-47 \mathrm{~m}$ where it caused a stratified mixture of run-up material, earth-slid material and river deposits. The tsunamite wedges out in Site 16 in varve $1171 \mathrm{BC}(3121 \mathrm{BP})$.

The $+33 \mathrm{~m}$ level has a very special shore-morphology with ridges, shore-spurs and erosion channels (Figure 34). We cored the Lintjärnen bog and retrieved the tsunami bed covered by 13 varves and a peat cover. Gyttja in varve 13 was C14-dated at $1306 \pm 87$ cal. yrs BC. The date represents redeposited organic matter from the tsunami run-up. 


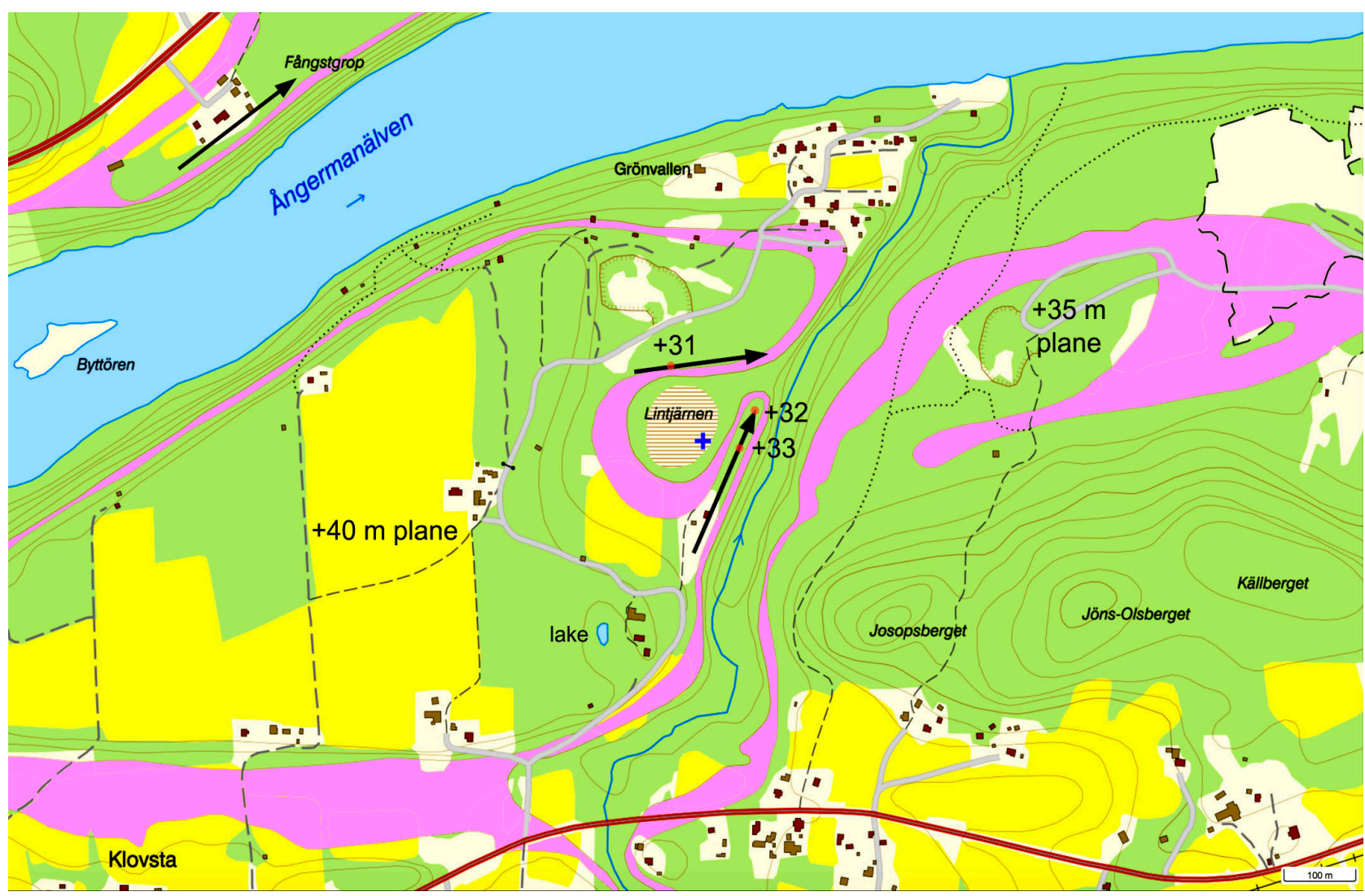

Figure 34. The shore morphology at Klovsta at River Ångermanälven. At the time of the tsunami, sea level was at $+33 \mathrm{~m}$. The +25 to $+30 \mathrm{~m}$ contours are marked in purple. Just at this level there are shore-morphological criteria of spur ridges (black arrows) and erosion channels (purple). Sediment coring was done in the Lintjärnen bog.

In conclusion, we think we can now provide an absolute annual age of the mega-tsunami at Ångermanälven of 1171 yrs BC or 3121 yrs BP. The C14-date in the varve above of $1306 \pm 87$ cal. yrs BP represents redeposited organic matter set in suspension at the tsunami run-up (Appendix). Besides, we determine the run-up at about $14 \mathrm{~m}$ and the submarine bedload effects at about $10 \mathrm{~m}$.

This analysis was undertaken in April-June 2020. The absolute date established fits well with previous dates (Appendix) and papers [10] [11] [24].

\section{Discussion: Geology}

There are two points of general implication that need to be mentioned before our general discussion; that is the C14-datings and the reference level of elevation.

All our C14 dates refer to AMS-dates with absolute age calibration according to Reimer et al. [46]. Older dates referred to in connection to archaeological material may be calibrated with older standards. The differences are small, however. In a few cases [37] the dates refer to the old pre-AMS technique. The ages given in the text are either C14-ages in years BP (i.e. before 1950) or in calibrated yeas BC, "cal. yrs BC", (in a few cases in cal. yrs AD). 
The reference level of elevation is more complicated. The national reference system (Swed: Rikets höjdsystem, RH) was originally fixed to year 1900 (HY00), later to year 1970 (HY70) and finally to year 2000 (HY2000). Because the rate of absolute isostatic uplift in Stockholm is determined at $4.9 \mathrm{~mm} /$ year [47] [48], the choice of reference level will add uncertainties when combining different observations and elevation contour lines. This is, for example, the case with the height values of most of the cores (A-Z) which in general were determined from maps based on the RH2000 system. It is not clear to what reference level the archaeological sites at Annelund (3.1) and Apalle (3.4) are related. Because both sites refer to the construction of the new highway, they are likely to be related to the HY70 system.

The sea level position at the time of the mega-tsunami is estimated from the known rate of uplift, giving an elevation of $+15.5 \mathrm{~m}$ for HY2000, $+15.2 \mathrm{~m}$ BP for 1950 (C14) and $+15.0 \mathrm{~m}$ for HY00. Because the eustatic component is likely to have been slightly below present sea level, $+15.0 \mathrm{~m}$ was chosen as likely sea level position at the time of the mega event. Back in time, the rate of isostatic uplift has increased, but for the last 3000 years it seems to have remained stable [47]. We may therefore, conclude that sea level 3121 years before HY200 is likely to have been at $+15 \mathrm{~m}$ to $+16 \mathrm{~m}$. In this paper we used $+15 \mathrm{~m}$.

\subsection{General Discussion}

At about $3000 \mathrm{BP}$ or $1200 \mathrm{cal}$. yrs BP something both unique and revolutionary happened: the Kaali impact occurred in Estonia (e.g. [49]) and initiated violent ground shaking, methane venting tectonics and a mega-tsunami affecting the whole of the Baltic [2] [10] [11] [22]. In this paper, we have explored the tsunami effects in general and specifically in the Enköping area. We have combined geological and archaeological data, and, indeed, where ever we work, we find evidence of a major tsunami event at about $3000 \mathrm{BP}$ when sea level was at about $+15 \mathrm{~m}$ in the Stockholm area.

We found the following tsunami run-up values (Figure 1):

- at least $11 \mathrm{~m}$ in Umeå

- about $14 \mathrm{~m}$ at River Ångermanälven

- at least $12 \mathrm{~m}$ in Hudiksvall

- more than $6 \mathrm{~m}$ in Forsmark (maybe $21.5 \mathrm{~m}$ )

- about $20.5 \mathrm{~m}$ in Upplands-Väsby

- about $13.5 \mathrm{~m}$ in Annelund, Enköping

- about $14.5 \mathrm{~m}$ in Boglösa, Enköping

- at least $14.5 \mathrm{~m}$ at Janslunda, Eskilstuna

- at least $13.5 \mathrm{~m}$ in the Håbo area, Bålsta

- about $16.5 \mathrm{~m}$ in Apalle, Bålsta

- at least $14.5 \mathrm{~m}$ at Långaedet cores, Åker

- probably $19 \mathrm{~m}$ at Långaedet gully, Åker

- at least 9 (probably 10) $\mathrm{m}$ in Saltsjöbaden 
- at least $10 \mathrm{~m}$ at Fituna-Kvarnberget, Södertörn

- about $16.5 \mathrm{~m}$ at Tystberga

The documentation is extensive. The run-up values differ from about $10 \mathrm{~m}$ to about $15 \pm 1.5 \mathrm{~m}$, maybe even $19-20.5 \mathrm{~m}$. This is not at all surprising because the run-up level is not fixed but varies with several parameters like exposure, off-shore slope, land topography, interference of waves [12].

In our case, we also have records of the off-shore effects on the seabed (Figure 3), with erosion going down 13.5 - $14.5 \mathrm{~m}$ below the sea level 3000 years ago: at +15 m (Figure 14). With such a deep off-shore effect, it is quite natural to have the run-up wave over land, at least, as high as this and even somewhat higher.

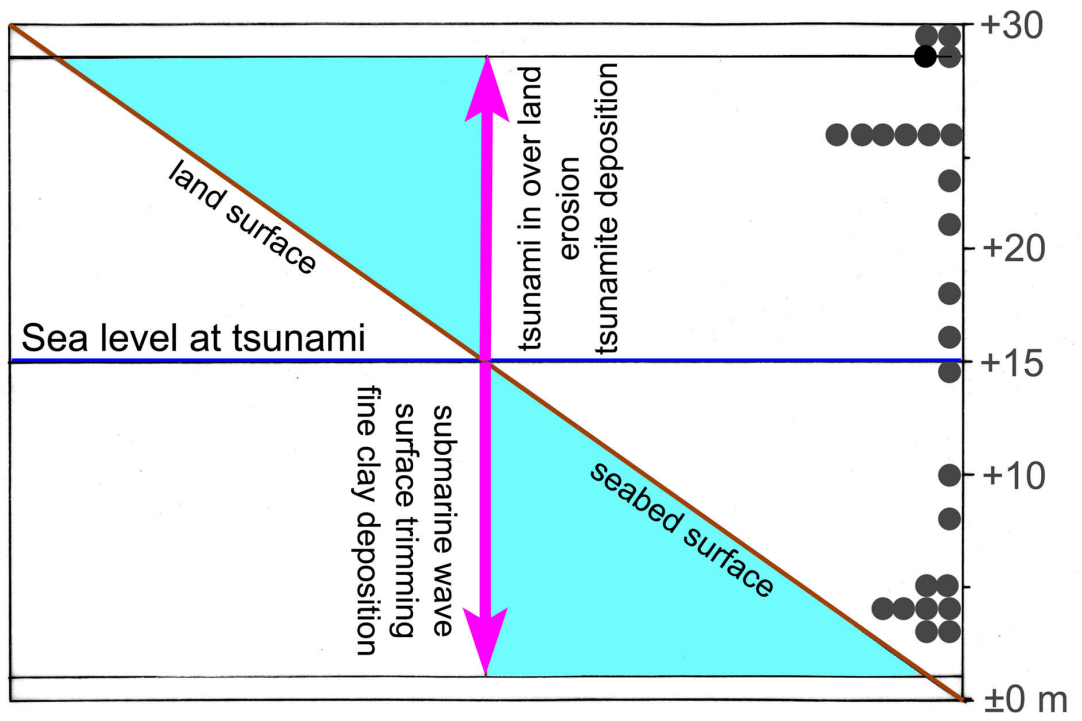

Figure 35. Core records of the tsunami wave submarine seabed surface trimming below sea level at the tsunami event (+15 $\mathrm{m}$ at $3000 \mathrm{BP})$ and the on-land run-up and tsunamite deposition in the Enköping-Bålsta area (black dots refer to elevation of cores retrieved). The tsunami amplitude is $+15 \mathrm{~m} \pm 1.5 \mathrm{~m}$ (pink arrows). In the land area, the run-up may occasionally go up to $19-20.5 \mathrm{~m}$, however.

Because the Enköping-Uppsala-Stockholm area is a lowland characterized by clay deposition, the tsunami wave sent up clouds of fine clay particles in suspension. This led to the deposition of fine clay beds in the off-shore area. The tsunami run-up over land, usually led to severe erosion; sometimes the erosion went down all the way into the glacially varved clay, leaving a hiatus of about 7000 - 8000 years below the tsunamite.

Figure 35 graph is quite unique in recording both the on-shore run-up values, and the submarine erosional/depositional effects. The tsunami deformations are symmetrically ordered in $\pm 13.5 \mathrm{~m}$ around the $+15 \mathrm{~m}$ sea level at the time of the mega-tsunami event. This implies quite symmetrical waves (Figure 36) before the tsunami hits the coast and runs-up over the land surface causing erosion, deformation and re-deposition (as observed by coring, e.g. Figure 13, and reinterpretation of archaeological data; e.g. Figure 25, Figure 27). 


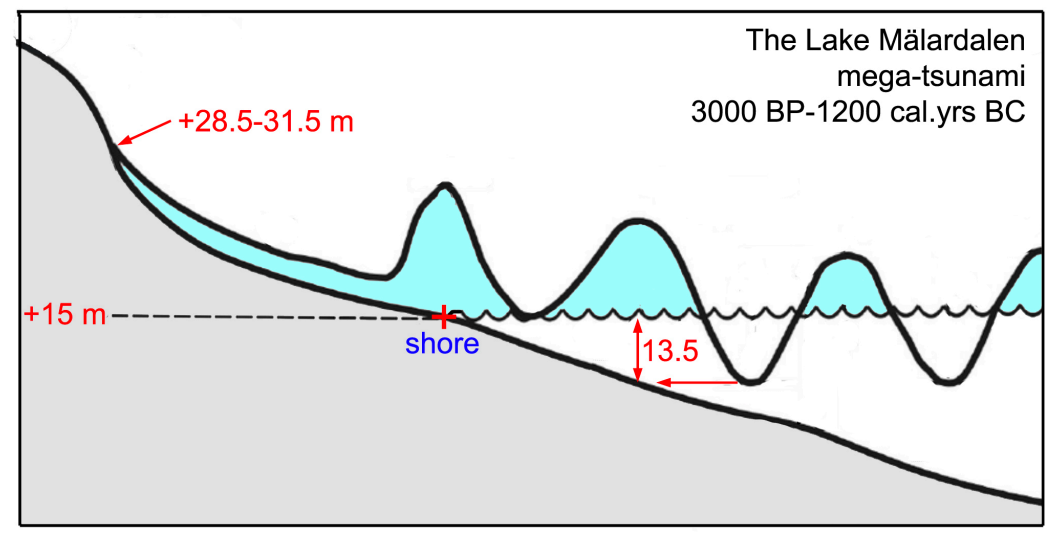

Figure 36. Synthetic image of the tsunami records in the Lake Mälaren region; a maga tsunami with a wave amplitude of about $\pm 13.5 \mathrm{~m}$ and a run-up of 13.5 16.5 or even more.

\subsection{Additional Data}

It seems where ever we go, we find new examples of the Mid Bronze Age tsunami event. At Björklinge (20 km north of Uppsala; [50]), hearths with artefacts and bones were found at $+36 \mathrm{~m}$ and $+34 \mathrm{~m}$ (site Tibble II) covered by $10-15 \mathrm{~cm}$ of gravelly sand with occasional stones; earlier considered "remarkable", now perfectly well understood in terms of the $3000 \mathrm{BP}$ tsunami event. At a close-by site (Tibble III), there was a hearth at $+30.6 \mathrm{~m}$ including a flint tool from the Bronze Age. The hearth was covered by $15 \mathrm{~cm}$ of gravelly sand; obviously from our $3000 \mathrm{BP}$ tsunami event.

The thin layers of gravelly sand at Björklinge are typical tsunami deposits, like the "silt layer" at Annelund (above). Similar layers are recorded at former tsunami events all over to globe. They were also observed at the huge Indonesian tsunami in December, 2004 [51] [52] [53].

Even a thin layer of sand and silt may alter the permeability of a tsunami-flooded bed. This may change the drainage conditions and, for example, initiate peat formation. Deposition of gyttja may act as a fertilizer.

A tsunami may also lead to severe costal destruction [14] [27]. Ridges and mounds may become remodelled to flat surfaces, and heavy objects like boulders may become relocated [51].

\subsection{Gillberga Gryt in NE Uppland Revisited}

Gillberga Gryt refers to a violent bedrock deformation, where a previous "roche moutonnée" has been deformed into a heap of huge angular blocks, often with one surface representing the old glacially polished surface, indicating that the deformation took place in postglacial time [2] [17] [54]. It was interpreted in terms of a high-magnitude earthquake occurring about 10,000 BP [2] [54]. The bedrock deformation is bounded to the north by an extensive peat bog at an elevation of $+20 \mathrm{~m}$. The level implied that the tsunami event was likely to be recorded in the bog stratigraphy. 
We undertook an extensive coring program in the bog (Figure 37). The profile is $130 \mathrm{~m}$ long and contains 7 coring sites. In sites 1 and 2 additional cores were taken at $1 \mathrm{~m}$ interval to record the topography of the rock surface that stopped deeper coring. It reveals a heavily irregular surface indicating the presence of blocks $14 \mathrm{~m}$ (1) and $30 \mathrm{~m}$ (2) from the present foot of Gillberga Gryt (angular blocks). From sites 5 to 8, a typical tsunami layer extends over at least $86 \mathrm{~m}$ (just as the layers we recorded at so many places in the Lake Mälaren region). The tsunami bed consists of fine sand and silt and reworked gyttja with occasional pebbles. It exhibits graded bedding in cores 5 and 6 .

Gillberga Gryt lies just to the south of the Forsmark area from where a tsunami was recorded at several sits ([7] and Supporting Material to [11]).

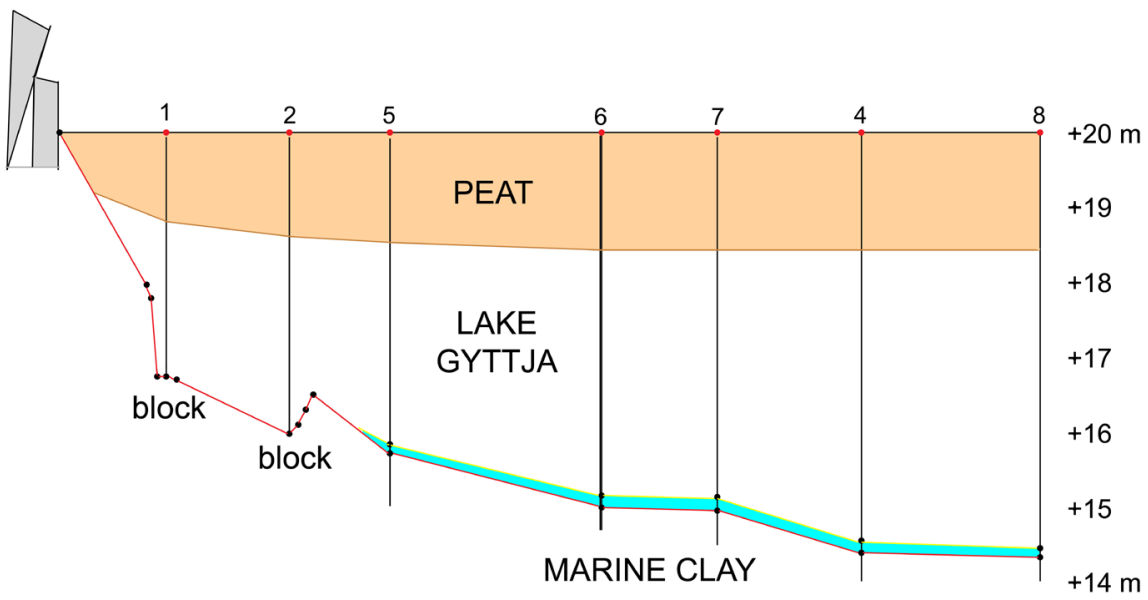

Figure 37. Sediment profile in the bog immediately to the north of Gillberga Gryt. A typical tsynami bed is recorded between site 5 and 8 ( $86 \mathrm{~m}$ apart). It consists of sand and silt and silty gyttja, in graded (fining upward) bedding in cores 5 and 6 .

\section{Archaeological Perspectives}

This paper presents geological evidence suggesting the occurrence of a mega-tsunami in eastern Sweden around 3000 BP, more exactly 1171 BC. A primary question is whether this catastrophe is also traceable in the archaeological material of the Lake Mälaren region. For archaeologists, there are several key and methodological problems, not least: what is there to look for, where is such evidence found and what is important to document and analyze?

The above discussions have looked at three examples of anomalies documented in earlier archaeological excavations that have been described as difficult to understand or unusually explained archaeologically: at Annelund, Apalle and Björklinge. These have all followed contemporary archaeological practices and praxes. The first two took place in the mid-1980s during a dynamic period of archaeological development and administrative change and an intensive period of field work involving excavations and ancient monument surveys. This led to new archaeological understandings of settlement variations and the cultural materials of Bronze Age and their results became the focus of many studies (J. 
Anund in [16]). Previously, very few excavations had been carried out in the Trögden and Håbo areas, and discovery of evidence suggesting a tsunami catastrophe was still a decade farther into the future.

Here, attempts have been made to include perspectives of two complex and independent disciplines, each of which works with complicated and independent processes: natural geological and human activity. Geological raw materials are undeniably mutual to both disciplines-soils and rocks-where the distinction between the two is not wholly distinct. When do geological materials and evidence of natural processes become part of the scope of archaeological processes as evidence reflecting human activity: artifacts, ancient monuments, humanly created cultural layers and stratigraphy? In many instances, these are inextricably intertwined. From an archaeological perspective, this is not an obvious question and there is no standardized answer (Anderson Ambrosiani, forthcoming).

Since the early 1900s, principles of the natural processes of isostasy and eustasy have been used in archaeological fieldwork. Isometric information was a key factor combined with excavation results in early Swedish archaeological settlement studies [55]. Archaeologists have continued to use such landscape information as a tool in fieldwork: in surveys and excavations, in interpreting ancient monument distributions and in developing and discussing models of settlement development.

However, it is as obvious to archaeologists that archaeological phenomena cannot be fully explained by geology as the opposite is to geologists. At the same time, experiences from this exploratory project and paper suggest that knowledge of such an event can be potentially interesting to archaeology with new possibilities for archaeological research. Adding such a perspective to theoretical and archaeological practices and praxes is a challenge to archaeological fieldwork and explanation alike. For archaeology, exploration and interpretation of sites and materials must be carried out source critically with a foothold in archaeology and respectfully, with the goal of maintaining the authenticity and integrity of the archaeological materials.

Future ancient monument studies and archaeological excavations, particularly in the Lake Mälaren region, that deem these possibilities interesting and worthwhile to explore further, may formulate research questions and create strategies for identification and documentation already in the planning stages. This event may create a post- and ante quem for a long prehistoric period that until now has lacked a fixed chronological point in time. Cultural materials from the Lake Mälaren region, roughly from Period III, the time of the tsunami and the transition between the early and late Bronze Age, have long been notably scarce.

\section{Conclusions}

The tsunami records from Umeå, Hudiksvall, Forsmark, Upplands-Väsby, Saltsjöbaden, Åker, Södertörn, and Tystberga, all occurring at about 3000 BP, were in this paper put to a detailed test and analysis with respect to geology and 
archaeology in the Enköping-Bålsta area. The new data provide evidence that, indeed, the area was struck by a violent tsunami at about $3000 \mathrm{BP}$ or about 1200 cal. yrs BC.

The on-shore tsunami run-up was determined at $+13.5 \mathrm{~m}$ at Annelund, +14.5 $\mathrm{m}$ at Boglösa, $+13.5 \mathrm{~m}$ in the Håbo area and $+16.5 \mathrm{~m}$ at the Apalle archaeological site.

In the off-shore area traces of erosion and deposition of fine particles in tsunami suspension were traced 13.5 - $14.5 \mathrm{~m}$ below sea level (Figure 35 ).

The tracing of a tsunami wave, both in the on-land run-up phase and the off-shore erosional phase, is unique and acts as a confirmation of the tsunami episode.

The exact timing of the tsunami differs somewhat. The dates referring to the tsunami event itself fall within 2900 - 3070 BP or 1100 - 1300 cal. yrs BC (i.e. $1200 \pm 100 \mathrm{BC}$ ). There are a number of dates pre-dating the tsunami; their age falls within $3400-3000 \mathrm{BP}$ or 1650 - 1300 cal. yrs BC. There is also a group of dates post-dating the tsunami; their ages are $<2900 \mathrm{BP}$ or $<1100 \mathrm{cal}$. yrs BC. The dates are compiled in Appendix.

At a late stage (April-June, 2020), the Ångermanälven analysis (Section 5) was performed. Evidence of the occurrence of a mega-tsunami was established, and it was found that the tsunami must have occurred in varve-year $1171 \mathrm{BC}$ or 3121 $\mathrm{BP}$, an age which fits perfectly well with previous C14-dates of the tsunami event in Sweden (Appendix, [10] [11] and the age of the Kaali impact [10] [11] [49].

The occurrence of a tsunami wave (or sequence of two or more waves) with a run-up amplitude of $10 \mathrm{~m}$ to about $15 \mathrm{~m} \pm 1.5 \mathrm{~m}$, maybe even $19-20.5 \mathrm{~m}$, in the middle of the Bronze Age will have wide, maybe even revolutionary, effects on our understanding of the archaeological evolution during the Bronze Age. We have analysed the records from Annelund and Apalle, and been able to propose significant reinterpretations. We feel that this is just the beginning, however.

The Brandskogsskeppet rock-carving is also considered in relation to the tsunami. The level of the rock surface at $+28.5 \mathrm{~m}$ coincides with the tsunami run-up in the Boglösa area.

The western part of the Lake Mälaren region and the Lake Hjälmaren region are in need of extended analyses, like the whole of the South Baltic area. It is our sincere hope that our paper will inspire such studies.

\section{Acknowledgements}

We are indebted to David Mörner for kind and skilful assistance in the coring campaign in the Enköping-Bålsta area, to Pamela Matlack-Klein for her professional linguistic review, and to Anders Wall at SGU for kind assistance with literature. We declare no conflict of interest. We have no founding to acknowledge. The radiocarbon dates were performed at the Ångström Laboratory at Uppsala University and paid for by Upplands Väsby municipality, Paniba HB (BA, PAA) and NAM. 


\section{Conflicts of Interest}

The authors declare no conflicts of interest regarding the publication of this paper.

\section{References}

[1] Mörner, N.-A. (1991) Intense Earthquakes and Seismotectonics as a Function of Glacial Isostasy. Tectonophysics, 188, 407-410. https://doi.org/10.1016/0040-1951(91)90471-4

[2] Mörner, N.-A. (2003) Paleoseismicity of Sweden: A Novel Paradigm. A Contribution to INQUA from Its Sub-Commission on Paleoseismology at 16th International INQUA Congress in Reno, Nevada. Stockholm University, P\&G Print, 1-320.

[3] Mörner, N.-A. (2011) Paleoseismology: The Application of Multiple Parameters in Four Case Studies in Sweden. Quaternary International, 242, 65-75. https://doi.org/10.1016/j.quaint.2011.03.054

[4] Mörner, N.-A. (1996) Jättejordbävning skakade Mälardalen för 10.476 år sedan. Forskning \& Framsteg, 5/96, 30-33.

[5] Mörner, N.-A. (1996) Liquefaction and Varve Disturbace as Evidence of Paleoseismic Events and Tsunami: The Autumn 10,430 BP Event in Sweden. Quaternary Science Reviews, 15, 939-948. https://doi.org/10.1016/S0277-3791(96)00057-1

[6] Mörner, N.-A. (1999) Paleo-Tsunamis in Sweden. Physics and Chemistry of the Earth (B), 24, 443-448. https://doi.org/10.1016/S1464-1909(99)00026-X

[7] Mörner, N.-A. and Dawson, S. (2011) Traces of Tsunami Events in Off- and On-Shore Environments. Case Studies in the Maldives, Scotland and Sweden. In: Mörner, N.-A., Ed., The Tsunami Threat-Research \& Technology, Chapter 18, InTech, London, 371-388. https://doi.org/10.5772/13686

[8] Mörner, N.-A. (2016) Tsunamis in Sweden: Occurrence and Characteristics. In: Mokhtari, M., Ed., Tsunami, InTech, London, 115-133. https://doi.org/10.5772/63956

[9] Mörner, N.-A. (2017) Converting Tsunami Wave Heights to Earthquake Magnitudes. Open Journal of Earthquake Research, 6, 89-97.

https://doi.org/10.4236/ojer.2017.62005

[10] Mörner, N.-A. (2020) The Kaali Impact, Coincidental Deformations and Tsunamis, and Ancient Legends. 10th International INQUA Meeting on Paleoseismology, Active Tectonics and Archeoseismology (PATA), Hornitos, 8-12 November 2020, Extended Abstracts, 1-4.

[11] Mörner, N.-A. (2020) The Kaali Impact as Trigger of a Mega-Tsunami Event and Violent Seismotectonics in Sweden. International Journal of Astronomy and Astrophysics, 10, 235-246.

https://www.researchgate.net/publication/344287444 Supplementary Materials Ob servational facts on seismotectonics and a mega-tsunami in Sweden Searching for a larger meteor fragment falling into the Baltic Sea\#fullTextFileContent

[12] Röbke, B.R. and Vött, A. (2017) The Tsunami Phenomenon. Progress in Oceanography, 159, 296-322. https://doi.org/10.1016/j.pocean.2017.09.003

[13] Mörner, N.-A., Laborel, J. and Dawson, S. (2008) Submarine "Sandstorms" and Tsunami Events in the Indian Ocean. Journal of Coastal Research, 24, 1608-1611. https://doi.org/10.2112/07-0977.1

[14] Tanaka, H., Tihn, N.X., Umeda, M., Hirao, R., Pradjoko, E., Mano, A. and Udo, K. 
(2012) Coastal and Estuarine Morphology Changes Induced by the 2011 Great East Japan Earthquake Tsunami. Coastal Engineering Journal, 54, Article ID: 1250010. https://doi.org/10.1142/S0578563412500106

[15] Fagerlund, D. and Hamilton, J. (1995) Annelund-en hällkista från senneolitikum och bronsålder. RAÄ 17 och 84, Stenvreten 8:22 och 8:3, Enköpings stad, Uppland. Riksantikvarieämbetet, UV-Uppsala, Rapport 1995:13.

[16] Ullén, I. (2003) Bronsåldersplatsen vid Apalle i Uppland. Arkeologi på vägundersökningar för E18. Riksantikvarieämbetet, UV Uppsala Rapport 1997:64. $1-329$.

[17] Möller, H. (1977) Beskrivning till Jordarskartan Enköping SO (the Map from 1975). Sveriges Geologiska Undersökning, Ae-20, 1-68.

[18] Möller, H. (1977) Beskrivning till Jordarskartan Enköping SV. Sveriges Geologiska Undersökning, Ae-26, 1-64.

[19] Magnusson, E. (1984) Beskrivning till Jordarskartan Västerås SO. Sveriges Geologiska Undersökning, Ae-64, 1-76.

[20] Björnbom, S. (1983). Beskrivning till Jordarskartan Enköping SO (the Map from 1975). Sveriges Geologiska Undersökning, Ae-60, 1-62.

[21] Sjöberg, R. (2018) Vad hände efter Norrlandskusten för tre till fyratusen år sedan? Grottan, 2018, 39-45.

[22] Mörner, N.-A. (2017) Methane Hydrate in Crystalline Bedrock and Explosive Methane Venting Tectonics. Earth-Science Reviews, 169, 202-212. https://doi.org/10.1016/j.earscirev.2017.05.003

[23] Mörner, N.-A. (2009) Late Holocene Earthquake Geology in Sweden. Geological Society London Special Publications, 316, 179-188.

https://doi.org/10.1144/SP316.11

[24] Ambrosiani, B. and Ambrosiani, P.A. (2020) Tolan i Upplands-Väsby; ett gravfält från bronsåldern, including a section by N.-A. Mörner on "En omskakande geologisk händelse 1200 år f.Kr.”.

[25] Mörner, N.-A. and Strandberg, S. (2009) Marviken. Geologiskt baerad namntolkning. Saga och Sed, Kungl. Gustav Adolfs Akademinens Årsbok 2009, 179-184.

[26] Mörner, N.-A. and Sjöberg, R. (2011) Excursion Guide 2nd International Conference on Granite Caves, Sweden. Speleo Publication 12, 1-28.

[27] Mörner, N.-A. (2019) Tsunami Deposits. In: Finkl, C.W. and Makowski, C., Eds., Encyclopedia of Coastal Science, 2nd Edition, Springer, Berlin, 1805-1808. https://doi.org/10.1007/978-3-319-93806-6 369

[28] Andersson, K., Biwall, A., Frölund, P., Holm, J., Rosborg, B., Waks, G. and Wrang, L. (1995) Tibble-begyggelse och gravar i norra Trögden. Arkeologi på väg-undersökningar för E18. Riksantikvarieämbetet, UV Uppsala Rapport 1994:52, 1-340.

[29] Nordén, A. (1925) Brandskogs-skeppet: Vår bronsålders märkligaste skeppsbild. Fornvännen, 20, 376-391. https://doi.org/10.1086/cp.20.4.263447

[30] Kjellén, E. (1976) Upplands hällristningar. Kungl. Vitterhets-, Historie-och Antikvitetsakademien, Monografier 56, 1-196.

[31] Mörner, N.-A. (1999) Sea Level and Climate. Rapid Regressions at Local Warm Phases. Quaternary International, 60, 75-82.

https://doi.org/10.1016/S1040-6182(99)00008-7

[32] Sernander, R. (1910) Die Schwedischen Torfmoore als Zeugen post-glazialer Klimaschwankungen. Die Veränderungen des Klima seit dem Maximum der letzten Eiszeit, XI International Geological Congress, Stockholm, 197-246. 
[33] Ullén, I., Ranheden, H., Eriksson, T. and Engelmark, R. (1995) Om brunnararkeologiska och botaniska studier på Håbolandet. Riksantikvarieämbetet, Arkeologiska Undersökningar, No. 12, 1-82.

[34] Ranheden, H. (1995) Bronsåldersbrunnen i Apalle-en arkepbotanisk diskussion. Riksantikvarieämbetet, Arkeologiska Undersökningar, No. 12, 29-37. https://doi.org/10.1007/978-3-642-85433-0 5

[35] Ranheden, H. (1995) Järnåldersbrunnen i Skälby-en markprocesssuell diskussion. Riksantikvarieämbetet, Arkeologiska Undersökningar, No. 12, 69-82.

[36] Magnusson, R. (2010) Apalle och andra bronsåldersboplatser i Mälardalen. Var det byar? Master Thesis in Archaeology, Gothenburg University, Gothenburg, 35 p.

[37] Robertsson, A.M. (1991) Strandförskjutningen i Eskilstunatrakten ca 9000 till 4000 år sedan. Sveriges Geologiska Undersökning, Rapporter och meddelanden, No. 67, $1-27$.

[38] Henckel, H. (2012) Urtid-Istid-Nutid: Geologisk vandring i Törnskogen. Naturskydds föreningen i Sollentuna. $36 \mathrm{p}$.

[39] Florin, S. (1961) Djupvik, eine ostschwedische Fischersiedlung vom Ende der Steinzeit. Bulletin of the Geological Institution of the University of Uppsala, 60, 315-364.

[40] Lidén, R. (1938) Den senkvartära strandförskjutningens förlopp och kronologi i Ångermanland. Geologiska Föreningen i Stockholm Förhandlingar, 60, 397-404. https://doi.org/10.1080/11035893809445012

[41] Cato, I. (1987) On the Definite Connection of the Swedish Time Scale with the Present. Sveriges Geologiska Undersökning, Uppsala, Ca 68, 1-55.

[42] Cato, I. (1998) Ragnar Lidéns postglacial varve chronology from the Ångermanlanälven valley, northern Sweden. Sveriges Geologiska Undersökning, Uppsala, Ca 88, 1-88.

[43] Cato, I. (1992) Shore Displacement Data Based on Lake Isolations Confirm the Postglacial Part of the Swedish Geochronological Time Scale. Sveriges Geologiska Undersökning, Uppsala, Ca 81, 75-80.

[44] Segerström, U., Renberg, I. and Wallin, J.-E. (1984) Annual Sediment Accumulation and Land Use History: Investigations of Varved Lake Sediments. Verhandelungen Internationale Vereinigung für Theoretische und Angewandte Limnologie, 22, 1396-1403. https://doi.org/10.1080/03680770.1983.11897507

[45] Wallin, J.-A. (1993) Den fasta jordbruksnäringens utveckling I Ångermanälvens nedre dalgång under järnålder och medeltiden: En paleoekologisk undersökning. Acta Antiqua Ostrobothniensia, 3.

[46] Reimer, P.J., Bard, E., Bayliss, A., Beck, J.W., et al. (2013) IntCal13 and Marine13 Radiocarbon Age Calibration Curves 0 - 50,000 Years cal BP. Radiocarbon, 55, 1869-1887. https://doi.org/10.2458/azu js rc.55.16947

[47] Mörner, N.-A. (1973) Eustatic Changes during the Last 300 Years. Palaeogeography, Palaeoclimatology, Palaeoecology, 13, 1-14. https://doi.org/10.1016/0031-0182(73)90046-1

[48] Mörner, N.-A. (1991) Course and Origin of the Fennoscandian Uplift: The Case of Two Different Mechanisms. Terra Nova, 3, 408-413. https://doi.org/10.1111/j.1365-3121.1991.tb00170.x

[49] Veski, S., Heinsalu, A., Lang, V., Kestlane, Ü. and Possnert, G. (2004) The Age of the Kaali Meteorite Craters and the Effect of the Impact on the Environment and Man: Evidence from inside the Kaali Craters, Island of Saaremaa, Estonia. Vegeta- 
tion History and Archaeobotany, 13, 197-206. https://doi.org/10.1007/s00334-004-0043-x

[50] Segerberg, A. (1978) Stenåldersboplatser i Uppland. Nya utgrävningar vid Bälinge mossar, Tibble i Björklinge och Torslunda i Tierp. Årsboken Uppland, 7-32.

[51] Wagner, J.-F. and Chanchai, S. (2011) Grain-Size and Thin Sand Section Characteristics of Tsunami Sediments from Thai-Andeman Coast, Thailand. In: Mörner, N.-A., Ed., The Tsunami Threat-Research \& Technology, Chapter 13, InTech, London, 259-282.

[52] Jankaew, K., Martin, M.E., Sawai, Y. and Prendergast, A.L. (2011) Sand Sheets on a Beach-Ridge Plain in Thailand: Identification and Dating of Tsunami Deposits in a Far-Field Tropical Setting. In: Mörner, N.-A., Ed., The Tsunami Threat-Research \& Technology, Chapter 15, InTech, London, 299-324. https://doi.org/10.5772/14010

[53] Keating, B.H., Helsley, C.E., Wanink, M. and Walker, D. (2011) Tsunami Deposit Research: Fidility of the Tsunami Record, Ephemeral Nature, Tsunami Deposits Characteristics, Remobilization of Sediments by Later Waves, and Boulder Movements. In: Mörner, N.-A., Ed., The Tsunami Threat-Research \& Technology, Chapter 19, InTech, London, 389-422.

[54] Sjöberg, R. (1994) Bedrock Caves and Fractured Rock Surfaces in Sweden: Occurrence and Origin. PhD Thesis, P\&G-7, Stockholm University, Stockholm, 1-110.

[55] Ambrosiani, B. (1964) Fornlämningar och bebyggelse. Studier i Attundalands och Södertörns förhistoria, $\mathrm{PhD}$ Thesis, Uppsala University, Uppsala.

[56] Duffy, B. (2020) Radiocarbon Chronology of the Kaali Impact. Paper 2, 19-21, Supplementary Material to [11]. 


\section{Appendix}

The ages obtained are summarized in the list below organized in 3 categories with respect to the origin of the material dated (with BP-ages in C14-years, and BC-ages in cal. yrs BC). Category B "Contemporaneous" contains the dates of direct relevance for the dating of the mega-tsunami. With the varve date from Ångermanälven of $1171 \mathrm{BC}$, the other dates become ages confirming a general agreement. The category B dates have a spread of $1180 \pm 120 \mathrm{cal}$. yrs. BC in good agreement with the absolute varve date. The Kaali impact is dated at 1183-1162 cal. yrs BC [56]. The data are summarized in Figure 5 of paper [11].

\begin{tabular}{|c|c|c|c|}
\hline A: older than: & $3400-3000 \mathrm{BP}$ & $1650-1300 \mathrm{BC}$ & \\
\hline Apalle: pit & $3390 \pm 110$ & $1650 \pm 130$ & \\
\hline Umeå & $3345 \pm 080$ & $1635 \pm 115$ & \\
\hline Forsmark $+20.5 \mathrm{~m}$ & $3140 \pm 040$ & $1422 \pm 039$ & \\
\hline Apalle: veg. surface 6 & $3140 \pm 110$ & $1390 \pm 130$ & \\
\hline Apalle: well A1992 & $3110 \pm 030$ & $1370 \pm 042$ & \\
\hline Apalle: well A1640 & $3090 \pm 065$ & $1354 \pm 073$ & \\
\hline Apalle: ph-1 (1) & $3055 \pm 060$ & $1310 \pm 070$ & \\
\hline Apalle: well A1514 & $3045 \pm 055$ & $1303 \pm 077$ & \\
\hline Apalle: ph-2 (5 dates) & $3030 \pm 040$ & $1268 \pm 080$ & position uncertain \\
\hline B: contemporaneous & $2880-3070 \mathrm{BP}$ & $1060-1310 \mathrm{BC}$ & 1171 varves $B C$ \\
\hline Upplands-Väsby & $3073 \pm 033$ & $1315 \pm 085$ & \\
\hline Annelund & $3080 \pm 120$ & $1308 \pm 188$ & uncertain position \\
\hline Lintjärnen & $3043 \pm 029$ & $1306 \pm 087$ & redeposited organic \\
\hline Åker & $3055 \pm 070$ & $1303 \pm 091$ & \\
\hline Ångermanälven & 3121 & 1171 & varve date \\
\hline Site S (Figure 15) & 3125 & 1175 & sedimentation rate \\
\hline Site A (Figure 6) & $2965 \pm 031$ & $1160 \pm 110$ & \\
\hline Annelund & $2950 \pm 090$ & $1192 \pm 177$ & uncertain position \\
\hline Forsmark & $\sim 2900$ & $\sim 1100$ & mean values used \\
\hline$+12.5 \mathrm{~m}$ bog & $2920 \pm 045$ & $1129 \pm 075$ & \\
\hline$+8.0 \mathrm{~m} \mathrm{bog}$ & $2880 \pm 040$ & $1067 \pm 059$ & \\
\hline Site Y (Figure 23) & $2885 \pm 029$ & $1063 \pm 046$ & \\
\hline Apalle: building K10 & $2835 \pm 050$ & $1010 \pm 072$ & maybe younger than \\
\hline C: younger than & $<2800 \mathrm{BP}$ & $<1080 \mathrm{BC}$ & \\
\hline Apalle: ph-3 (6 dates) & $2880 \pm 065$ & $1080 \pm 095$ & \\
\hline Apalle: ph-4 (7 dates) & $2819 \pm 040$ & $993 \pm 040$ & \\
\hline Apalle: ph-5 (10 dates) & $2660 \pm 140$ & $790 \pm 195$ & \\
\hline
\end{tabular}

